\title{
Conceptual framework for capacity and intensity physical soil properties affected by short and long-term (14 years) continuous no-tillage and controlled traffic
}

\author{
José Miguel Reichert ${ }^{\mathrm{a}, *}$, Vanderleia Trevisan da Rosac ${ }^{\mathrm{c}}$, Eduardo Saldanha Vogelmann ${ }^{\mathrm{b}}$, \\ David Peres da Rosa ${ }^{c}$, Rainer Horn ${ }^{\mathrm{d}}$, Dalvan José Reinert ${ }^{\mathrm{a}}$, Arcenio Sattler ${ }^{\mathrm{e}}$, \\ José Eloir Denardin ${ }^{\mathrm{e}}$ \\ a Soils Department, Federal University of Santa Maria, Santa Maria, Brazil \\ b Biological Sciences Institute, Federal University of Rio Grande, São Lourenço do Sul, Brazil \\ ${ }^{\mathrm{c}}$ Federal Institute of Education, Sertão, Brazil \\ d Institute for Plant Nutrition and Soil Science, Christian-Albrechts-University zu Kiel, Kiel, Germany \\ ${ }^{\mathbf{e}}$ Brazilian Agricultural Research Corporation-National Research Center of Wheat, Passo Fundo, Brazil
}

\section{A R T I C L E I N F O}

\section{Article history:}

Received 13 March 2015

Received in revised form 4 November 2015 Accepted 21 November 2015

Available online 31 December 2015

\section{Keywords:}

Soil management

Air permeability

Saturated hydraulic conductivity

Porosity

Organic carbon

\begin{abstract}
A B S T R A C T
Recent studies have shown harmful effects of soil compaction in no-tillage system (NTS), but there are indications that soil structure improves with time of NTS adoption. We formulated the hypothesis that topsoils of NTS initially have worse soil physical conditions than those under conventional systems, but these conditions gradually improve with time also down to deeper depth, even when the soil is wheeled by farm machinery. Our objective was to evaluate the effect of a long-term no-tillage system and machine traffic on soil mechanical and hydraulic properties. The treatments and soil conditions consisted of five periods since the last conventional tillage (or age of NTS) in a Hapludox: 0.2, 1.5, 3.5, 5 and 14 years, with and without traffic; named recent tillage, and initial, intermediate, transition and stabilized NTS phases. Soil samples were collected from soil layers $0-7,7-14$ and $14-21 \mathrm{~cm}$ depth to determine soil porosity, precompression stress, compressibility coefficient, saturated hydraulic conductivity, air permeability, water retention curve, bulk density and organic carbon. Conventional tillage of soil previously under notillage significantly affected soil capacity properties, resulting in high macroporosity and deformation susceptibility, low bulk density and precompression stress. Intensity properties were affected initially by an increased soil pore obstruction, negatively affecting air permeability and saturated hydraulic conductivity, from 0 to $21 \mathrm{~cm}$ soil depth. However, after five years of no-tillage there was an increase in microporosity and, although small, in soil organic carbon, especially in the $0-7 \mathrm{~cm}$ soil layer; thus, soil water retention and soil intensity properties (like soil water and air permeability) were also improved, regardless of farm machinery traffic. Over time, soil reconsolidation occurred, which resulted in reduction of the compressibility coefficient and degree of compactness, mainly in the upper layers (07 and $7-14 \mathrm{~cm}$ ). However, in the deepest layer with the least disturbance, the degree-of-compactness and bulk density increased. The evolution of physical properties and processes (from recent tillage to stabilized NTS phase) for no-tilled soil is proposed for controlled and uncontrolled traffic systems as a framework based on field data for capacity and intensity soil properties. The process of creating aggregates is represented, at first, by an increased number of contact points before they are re-loosened and strengthened at the same time by a rearrangement of particles, reducing aggregate bulk density but increasing soil strength at the same time. The framework is divided into 4 phases: initial (1.5 years), intermediary ( 3.5 years), transitional ( 5 years), and stabilized (14 years) conditions.
\end{abstract}

(c) 2015 Elsevier B.V. All rights reserved.

\footnotetext{
* Corresponding author.

E-mail addresses: reichert@ufsm.br (J.M. Reichert), vandetrevisan@gmail.com (V.T. da Rosa), eduardovogelmann@hotmail.com (E.S. Vogelmann), david.rosa@sertao.ifrs.edu.br (D.P. da Rosa), rhorn@soils.uni-kiel.de (R. Horn), dalvanreinert@gmail.com (D.J. Reinert), vandetrevisan@gmail.com (A. Sattler), denardin@cnpt.embrapa.br (J.E. Denardin).
}

\section{Introduction}

Maintaining a proper balance between order and dissipation processes is fundamental for agricultural systems sustainability. Agricultural systems are thermodynamically open systems that 
tend toward steady-state, characterized by minimum production of entropy (Addiscott, 1995). Ordering processes and entropy decrease occur with plant photosynthesis and growth, organic matter formation, particle aggregation and development of soil structure, and water flow contributing to soil profile development (Addiscott, 1995).

The understanding of soil physical property dynamics is improved when using the concept of intensity and capacity soil properties, as proposed by Horn and Kutilek (2009). A capacity property (e.g., bulk density) is related to the composition of a defined soil volume, disregarding its internal organization, i.e., it ignores the structure and distribution of mineral and organic particles in the soil space. By contrast, an intensity property (e.g., air conductivity) considers the dynamic properties/processes that exhibit variations in time and space. Therefore, the latter is a tool to diagnose and quantify changes imposed by environmental and anthropic factors on soil internal structure and its functional properties or processes. Further, as stated by De Jong van Lier and Gubiani (2015), determining limiting conditions in a simplified manner goes against systemic understanding, since the actual functioning of the system is relegated to lower priority.

Many soils around the world under long-term conventional tillage (plowing and disking) are undergoing tillage shifting toward less soil perturbations. No-tillage system (NTS), for instance, is a farming system that considerably reduces soil erosion, sediment yield and, in much less extent, water loss in the landscape and at watershed scales (Engel et al., 2009; Bonumá et al., 2013, 2014; Didoné et al., 2014). This tillage system also promotes soil aggregate stabilization by the increased soil organic matter and decreased soil disturbance (Bernoux et al., 2006; Kihara et al., 2012). NTS has become the most widespread soil management system in Brazil, and it is expanding to crops that are still employing the conventional soil tillage (Cavalieri et al., 2009) and even substituting for slash-and-burn agriculture (Reichert et al., 2014, 2015a,b).

Soils under NTS frequently have higher state-of-compactness in farmland conditions (Reichert et al., 2009; Suzuki et al., 2013) and in forests and grazed pasture (Suzuki et al., 2015). Soil deformation, as the sum of soil shearing and compaction, may increase the demand of agricultural machinery traction (Horn et al., 1995; Botta et al., 2011), soil resistance to root penetration (da Veiga et al., 2007; Fasinmirin and Reichert, 2011), and water deficit during dry spells (Grzesiak et al., 2012; Awe et al., 2014). NTS may reduce soil volume explored by the rooting system (Reichert et al., 2009; Grzesiak et al., 2012), and soil macroporosity (Horn and Smucker, 2005), saturated hydraulic conductivity, and water storage (Bhattacharyya et al., 2006; Cavalieri et al., 2009).

These conditions, however, are generally observed in field experiments where the time after NTS adoption is not explicitly a study-variable (Fabrizzi et al., 2005; Li et al., 2011). Long-term studies (greater than 10 years), on the other hand, have shown different results than for short-term (a few years) research (Zibilske et al., 2002; Hazarika et al., 2009). They emphasized that long-term use of NTS could result in reduced soil bulk density, and improved aggregation, increased organic carbon content, and greater continuity and stability of soil pores. Horn (2004) proved that long term reduced tillage resulted in even deeper changes in soil strength. Soil precompression stress increased while, at the same time, the saturated hydraulic conductivity also increased down to even $60 \mathrm{~cm}$ depth after approximately 6 years of continuous tillage management.

We formulated the hypothesis that, in the first years of NTS adoption, capacity and intensity properties indicate worse soil quality than in conventional tillage, but soil conditions gradually improve over time with NTS even in trafficked field conditions. Our objective was to evaluate the effect of long-term no-tillage system and controlled farm machine traffic on soil capacity and intensity properties of a subtropical Hapludox.

\section{Materials and methods}

\subsection{Description of the study site, experimental design, and treatments}

The study was conducted at the experimental station of Brazilian Agricultural Research Corporation (EMBRAPA), Wheat Research Center, located in Passo Fundo, southern Brazil $\left(28^{\circ} 10^{\prime} 00^{\prime \prime} \mathrm{S}, 52^{\circ} 22^{\prime} 00^{\prime \prime} \mathrm{W}\right)$, at $680 \mathrm{~m}$ above the mean sea level. The soil is classified as Hapludox (Soil Survey Staff, 2014). The climate is humid subtropical (Cfa), according to the Köppen classification, with mean annual temperature of $17.5^{\circ} \mathrm{C}$, and average annual rainfall of $1785 \mathrm{~mm}$ evenly distributed throughout the year.

The experiment was laid out in randomized blocks using a twofactor experimental design, $5 \times 2$, i.e., five different times after tillage (ploughing and harrowing) of soil previously under notillage and two machine traffic levels, totaling 10 treatments or soil conditions (as they will be called onwards), with four replications each. A field under NTS since 1992 was used to establish our experiment in May 2001. The nine years of no-till prior to the initiation of this experiment were used for the 14 years (from 1992 to 2006) of continuous no-tillage treatment. Other five treatments were established by tilling the NTS area at different times, and then again managed under NTS, before soil sampling and observations were made in 2006, constituting the $0.2,1.5$, 3.5 and 5 years NTS treatments. After ploughing and harrowing operations, controlled machine traffic at two levels (with and without traffic) was established for all field operations. These procedures were repeated for adjacent portions of the field at five different times before soil sampling as mentioned above (Table 1 ). In all soil conditions, seeding was done with a seeder equipped with lagged-type disc furrow openers. The tractor used was a MF $2924 \times 2$ (total weight of $4.930 \mathrm{~kg}$ ) and seeder SHM 11/13 (total weight of $2.165 \mathrm{~kg}$ ). The cropping rotation used in the experimental area is described in Table 2.

\subsection{Soil sampling and laboratory analyses}

Soil sampling was done in December 2006. A 30-cm deep trench was excavated between crop rows in each plot to extract disturbed soil samples, from the soil layers $0-7,7-14$ and 14-

Table 1

Time since last tillage or time since the adoption of no-tillage system (NTS) and mont/year when was made the last soil tillage.

\begin{tabular}{lll}
\hline Abbreviation & Time since last tillage or time of NTS & Month/year of last tillage \\
\hline NTS $_{0.2}$ & 2 months since last tillage & October/2006 \\
NTS $_{1.5}$ & 1.5 years since last tillage & June $/ 2006$ \\
NTS $_{3.5}$ & 3.5 years since last tillage & June $/ 2003$ \\
NTS $_{5}$ & 5 years since last tillage & December $/ 2001$ \\
NTS $_{14}$ & 14 years since last tillage & December $/ 1992$ \\
\hline
\end{tabular}

Obs: the sampling for this study was done in December 2006. 
Table 2

Crop rotation used in the experiment.

\begin{tabular}{lll}
\hline Cropping season & Crop & \\
\cline { 2 - 3 } & Winter & Summer \\
\hline $2001 / 2002$ & Wheat & Soybean \\
$2002 / 2003$ & Vetch & Maize \\
$2003 / 2004$ & White oats & Soybean \\
$2004 / 2005$ & Wheat & Soybean \\
$2005 / 2006$ & Turnip & Maize \\
$2006 / 2007$ & White oats & Soybean \\
\hline
\end{tabular}

$21 \mathrm{~cm}$, to determine soil particle-size distribution and soil organic carbon. In the same soil layers, undisturbed soil samples were extracted with metallic rings (5.7-cm diameter and 4-cm height) to determine the saturated hydraulic conductivity (Ks), air permeability (Ka), total porosity (Pt), macroporosity (Ma), microporosity (Mi), bulk density (BD), compressibility, and soil water retention curve, in three replicates per layer and per treatment for each evaluation.

\subsubsection{Capacity properties analyses}

From disturbed soil samples, particle-size distribution, namely sand $(2.0-0.05 \mathrm{~mm})$, silt $(0.05-0.002 \mathrm{~mm})$ and clay $(<0.002 \mathrm{~mm})$ contents, was determined with the pipette method (Gee and Bauder, 1986), whereas soil organic carbon (SOC) content was quantified by the Walkley and Black (1934) method.

Soil Pt, Ma and Mi and water retention were determined in undisturbed soil samples, saturated by capillary rise for $48 \mathrm{~h}$ and subsequently drained to matric potentials of $-1,-6$ and $-10 \mathrm{kPa}$, in a sand column (Reinert and Reichert, 2006) and -33 and - $100 \mathrm{kPa}$ in pressure chamber (Klute, 1986). Thereafter, the samples were dried to constant weight in an oven at $105^{\circ} \mathrm{C}$ for $48 \mathrm{~h}$ to determine soil BD. Gravimetric soil moisture at matric potentials -500 , -1000 and $-1500 \mathrm{kPa}$ was determined in previously air-dried and sieved ( $2 \mathrm{~mm}$ sieve) soil samples, with a psychrometer (Klein et al., 2006; Gubiani et al., 2012). Volumetric soil moisture for each matric potential was calculated by multiplying the gravimetric moisture by the respective bulk density. Air capacity is the volume of empty pores at a given water potential; macroporosity is the volume of pores drained at $-6 \mathrm{kPa}$, and microporosity are waterfilled pores at $-6 \mathrm{kPa}$ water potential.

The soil water retention curve was obtained by the relationship between soil moisture and matric potential, with fitting of the Van Genuchten (1980) model. Field capacity (FC) and permanent wilting point (PWP) were calculated as water volume retained at -10 and $-1500 \mathrm{kPa}$ matric potential, respectively, from the model. The difference between soil water content at FC and PWP is defined as plant available water (Paw), whilst the difference between soil water content at saturation and field capacity $(\mathrm{FC}=-10 \mathrm{kPa})$ is drainable water (DW).

Soil degree-of-compactness (DC) relates field BD to a reference $\mathrm{BD}$ herein based on least limiting water range (LLWR):

$\mathrm{DC}=\frac{\mathrm{BD}}{\mathrm{BD}_{\mathrm{LLWR}}} 100$

where DC: degree-of-compactness (\%); BD: field bulk density $\left(\mathrm{Mg} \mathrm{m}^{-3}\right)$; $\mathrm{BD}_{\mathrm{LLWR}}$ : reference $\mathrm{BD}$ based on least limiting water range (LLWR), calculated as recommended by Reichert et al. (2009)

Table 3

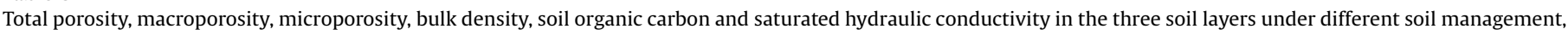
with and without machine traffic.

\begin{tabular}{|c|c|c|c|c|c|c|c|c|}
\hline \multirow{2}{*}{$\begin{array}{l}\text { Soil layer } \\
(\mathrm{cm})\end{array}$} & \multicolumn{5}{|c|}{ Management system } & \multicolumn{2}{|l|}{ Traffic } & \multirow[t]{2}{*}{$\mathrm{CV}(\%)$} \\
\hline & $\mathrm{NTS}_{0}$ & $\mathrm{NTS}_{1.5}$ & $\mathrm{NTS}_{3.5}$ & $\mathrm{NTS}_{5}$ & $\mathrm{NTS}_{14}$ & Without & With & \\
\hline \multicolumn{9}{|c|}{ Total porosity $\left(\mathrm{cm}^{3} \mathrm{~cm}^{-3}\right)$} \\
\hline $0-7$ & $0.69 \mathrm{a}^{\mathrm{a}}$ & $0.52 \mathrm{~b}$ & $0.53 \mathrm{~b}$ & $0.55 \mathrm{~b}$ & $0.54 \mathrm{~b}$ & $0.57^{\mathrm{ns}}$ & 0.56 & 8.3 \\
\hline $7-14$ & $0.60 \mathrm{a}$ & $0.51 \mathrm{~b}$ & $0.47 \mathrm{c}$ & $0.49 \mathrm{~b}$ & $0.48 \mathrm{bc}$ & $0.53 \mathrm{a}$ & $0.49 \mathrm{~b}$ & 4.5 \\
\hline $14-21$ & $0.50 \mathrm{a}$ & $0.50 \mathrm{a}$ & $0.49 \mathrm{ab}$ & $0.49 \mathrm{ab}$ & $0.49 \mathrm{~b}$ & $0.50^{\mathrm{ns}}$ & 0.50 & 5.6 \\
\hline \multicolumn{9}{|c|}{ Macroporosity $\left(\mathrm{cm}^{3} \mathrm{~cm}^{-3}\right)$} \\
\hline $0-7$ & $0.36 \mathrm{a}$ & $0.16 \mathrm{~b}$ & $0.19 \mathrm{~b}$ & $0.18 \mathrm{~b}$ & $0.12 \mathrm{~b}$ & $0.21^{\mathrm{ns}}$ & 0.19 & 26.5 \\
\hline $7-14$ & $0.27 \mathrm{a}$ & $0.16 \mathrm{~b}$ & $0.11 \mathrm{c}$ & $0.12 \mathrm{bc}$ & $0.11 \mathrm{c}$ & $0.18 \mathrm{a}$ & $0.13 \mathrm{~b}$ & 17.3 \\
\hline $14-21$ & $0.15 \mathrm{a}$ & $0.14 \mathrm{a}$ & $0.12 \mathrm{ab}$ & $0.13 \mathrm{ab}$ & $0.09 \mathrm{~b}$ & $0.12^{\mathrm{ns}}$ & 0.13 & 21.4 \\
\hline \multicolumn{9}{|c|}{ Microporosity $\left(\mathrm{cm}^{3} \mathrm{~cm}^{-3}\right)$} \\
\hline $0-7$ & $0.33 \mathrm{c}$ & $0.36 \mathrm{bc}$ & $0.34 \mathrm{bc}$ & $0.37 \mathrm{~b}$ & $0.42 \mathrm{a}$ & $0.35^{\mathrm{ns}}$ & 0.36 & 0.1 \\
\hline $7-14$ & $0.33 \mathrm{~b}$ & $0.35 \mathrm{ab}$ & $0.36 \mathrm{a}$ & $0.36 \mathrm{a}$ & $0.37 \mathrm{a}$ & $0.36^{\mathrm{ns}}$ & 0.35 & 3.5 \\
\hline $14-21$ & $0.36 \mathrm{c}$ & $0.36 \mathrm{bc}$ & $0.38 \mathrm{~b}$ & $0.37 \mathrm{bc}$ & $0.40 \mathrm{a}$ & $0.38 \mathrm{a}$ & $0.37 \mathrm{~b}$ & 3.0 \\
\hline \multicolumn{9}{|c|}{ Bulk density $\left(\mathrm{g} \mathrm{cm}^{-3}\right)$} \\
\hline $0-7$ & $1.17^{\mathrm{ns}}$ & 1.32 & 1.23 & 1.24 & 1.27 & $1.20 \mathrm{~b}$ & $1.29 \mathrm{a}$ & 6.8 \\
\hline $7-14$ & $1.27 \mathrm{~b}$ & $1.34 \mathrm{ab}$ & $1.41 \mathrm{a}$ & $1.41 \mathrm{a}$ & $1.36 \mathrm{ab}$ & $1.34^{\mathrm{ns}}$ & 1.38 & 5.6 \\
\hline $14-21$ & $1.45^{\mathrm{ns}}$ & 1.35 & 1.39 & 1.38 & 1.39 & $1.40^{\mathrm{ns}}$ & 1.38 & 4.8 \\
\hline \multicolumn{9}{|c|}{ Soil organic carbon (\%) } \\
\hline $0-7$ & $2.0 \mathrm{~b}$ & $1.7 \mathrm{c}$ & $1.7 \mathrm{c}$ & $2.2 \mathrm{a}$ & $2.1 \mathrm{ab}$ & $2.0 \mathrm{a}$ & $1.9 \mathrm{~b}$ & 3.6 \\
\hline $7-14$ & $1.6 \mathrm{bc}$ & $1.8 \mathrm{a}$ & $1.8 \mathrm{ab}$ & $1.6 \mathrm{c}$ & $1.6 \mathrm{bc}$ & $1.8 \mathrm{a}$ & $1.6 \mathrm{~b}$ & 4.6 \\
\hline $14-21$ & $1.6^{\mathrm{ns}}$ & 1.5 & 1.7 & 1.5 & 1.5 & $1.6^{\mathrm{ns}}$ & 1.5 & 5.2 \\
\hline \multicolumn{9}{|c|}{ Saturated hydraulic conductivity $\left(\mathrm{cm} \mathrm{h}^{-1}\right)$} \\
\hline $0-7$ & $47.0 \mathrm{a}$ & $7.8 \mathrm{~b}$ & $13.8 \mathrm{~b}$ & $13.5 \mathrm{~b}$ & $7.2 \mathrm{~b}$ & $19.3^{\mathrm{ns}}$ & 16.4 & 5.5 \\
\hline $7-14$ & $32.9 \mathrm{a}$ & $16.2 \mathrm{ab}$ & $8.0 \mathrm{~b}$ & $5.0 \mathrm{~b}$ & $15.4 \mathrm{ab}$ & $18.7^{\mathrm{ns}}$ & 11.4 & 9.0 \\
\hline $14-21$ & $10.6 \mathrm{a}$ & $5.0 \mathrm{~b}$ & $2.6 \mathrm{bc}$ & $4.8 \mathrm{bc}$ & $1.1 \mathrm{c}$ & $3.9 \mathrm{~b}$ & $5.7 \mathrm{a}$ & 4.4 \\
\hline
\end{tabular}

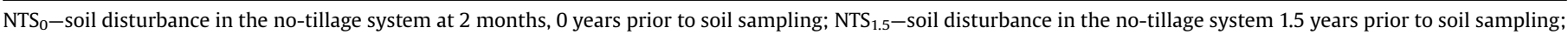

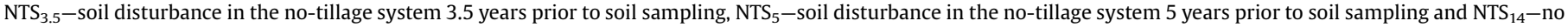
soil disturbance in the no-tillage system for 14 years prior to sampling. CV-coefficient of variation. ns-not significant.

a Means followed by the same letter in the same line do not differ by Tukey test $(p<0.05)$. 
where the $L L W R=0: B_{\text {LLWR }}=-0.00078$ clay +1.83803 , where clay is the clay content $\left(\mathrm{g} \mathrm{kg}^{-1}\right)$.

\subsubsection{Intensity property analyses}

For uniaxial compression test, soil samples were saturated and then equilibrated at a matric potential of $-33 \mathrm{kPa}$ using a pressure chamber (Klute, 1986). The tests were performed using a consolidometer with digital display of applied load, and analog readout of sample deformation. Soil samples were then sequentially loaded with $12.5,25,50,100,200,400,800$ and $1600 \mathrm{kPa}$. All loads were applied during $5 \mathrm{~min}$, when $99 \%$ of soil deformation had occurred (Reichert et al., 2009). Afterwards, the uniaxial compression curve was plotted, and values of precompression stress and coefficient of compressibility, which defines the slope of the virgin compression line (defined as anthropogenically affected), were determined by the Casagrande (1936) method.

Soil saturated hydraulic conductivity (Ks) was determined using a falling-head permeameter (Hartge and Horn, 2009; Gubiani et al., 2010).

Soil air permeability (Ka) was determined with a constant-head air permeameter, on soil samples equilibrated to $-6,-10,-33$, $-100,-300,-500$ and $-1500 \mathrm{kPa}$ matric potential. The equipment consisted of flow meters with different flow rates through which air circulates before flowing through soil. A low air pressure (0.1 kPa) was applied steadily to avoid turbulent flow. The pressure gradient between the environment and the air that flows through the sample was measured by the air flow meter. Ka was calculated by the equation:

$\mathrm{Ka}=\rho g \frac{0.001 \Delta v}{60 \Delta t 100 \Delta p a}$

where $\rho$ : air density $\left(\mathrm{kg} \mathrm{m}^{-3}\right)$; g: gravity $\left(9.81 \mathrm{~m} \mathrm{~s}^{-2}\right) ; \Delta t$ : interval time (s); $\Delta v$ : air volume $\left(\mathrm{m}^{3}\right)$ flowing through the soil during $\Delta t$; $\Delta p$ : applied air pressure $\left(\mathrm{kg} \mathrm{m} \mathrm{s}^{-2}\right)$; $a$ : sample cross sectional area $\left(\mathrm{m}^{2}\right)$.

Soil $K_{\mathrm{a}}$ and $\varepsilon_{\mathrm{a}}$ were regressed by logarithmic transformation similar to an exponential model of Ahuja et al. (1984), as previously proposed by Ball et al. (1988):

$\log K_{\mathrm{a}}=\log M+N \log \varepsilon_{\mathrm{a}}$

where $M$ and $N$ : empirical constants. $N$ is also regarded as a pore continuity index, which reflects an increase in $K_{\mathrm{a}}$ with increase in $\varepsilon_{\mathrm{a}}$ or reduction in pore tortuosity and surface area with larger amount of pores available for air flow.

Blocked soil porosity $\left(\varepsilon_{\mathrm{b}}\right)$ was estimated by the equation of Ball et al. (1988):

$\varepsilon_{\mathrm{b}}=10^{-\log M / N}$

where $\varepsilon_{\mathrm{b}}$ : value of $\varepsilon_{\mathrm{a}}$ below which the air flow through the soil ceases due to the discontinuity of the aerated pore network.

\subsection{Statistical analysis}

Capacity and intensity soil properties were tested for normal distribution using the Shapiro-Wilk test, and those not following a normal distribution (Ks and $\mathrm{Ka}$ ) were $\log$-transformed $(\log +1)$ before the ANOVA. When the F-test was significant, means were tested using Tukey $(p<0.05)$.

\section{Results}

\subsection{Capacity properties}

Soil organic carbon (SOC) decreased in the soil surface layer in the first years after tillage, $\mathrm{NTS}_{1.5}$ and $\mathrm{NTS}_{3.5}$, when compared to the initial content (2\%) found in $\mathrm{NTS}_{0.2}$ (Table 3 ). After five years of continuous no-tillage system, $\mathrm{NTS}_{5}$ and NTS ${ }_{14}$, SOC content began to increase and exceeded the initial content. Down to $14-\mathrm{cm}$ soil depth, farm machinery traffic had a significant effect on SOC, its content being greater in soil without traffic. However, in the 14$21 \mathrm{~cm}$ soil layer there was no significant effect of machine traffic on the SOC content (Table 3). The interaction between time of notillage adoption vs. machine traffic for surface layer of controlledtraffic soil was significant for SOC (Table 4). In the trafficked soil, $\mathrm{NTS}_{1.5}$ and $\mathrm{NTS}_{3.5}$ showed a reduction in SOC which differed significantly from other soil conditions. In the intermediate soil layer this interaction was also significant for SOC.

Soil total porosity (Pt) and macroporosity (Ma) were highest in the $0-7 \mathrm{~cm}$ soil layer of $\mathrm{NTS}_{0.2}$ (Table 3 ). In the intermediate layer $(7-14 \mathrm{~cm})$ significantly greater $\mathrm{Pt}$ and $\mathrm{Ma}$ values were also observed in $\mathrm{NTS}_{0.2}$ compared to other soil conditions. Despite high Pt and Ma recorded for $\mathrm{NTS}_{0}$ in $0-7 \mathrm{~cm}$ soil depth, lower soil bulk density (BD) was obtained in this layer compared to $\mathrm{NTS}_{3.5}$ and $\mathrm{NTS}_{5}$. Thus, with increasing time of NTS adoption, soil BD increased until reaching a maximum at about 3.5-5 years. However, in NTS ${ }_{14}$ BD values soil decreased with continuous notillage, thus indicating improved soil physical conditions. In this surface layer controlled-traffic significantly increased BD (Table 3 ).

Soil degree-of-compactness (DC) gradually decreased over time in both surface layers (0-7 and 7-14 cm), reaching values lower than those found in soil immediately after soil tillage (Fig. 1). In contrast, in the deepest layer, DC increased significantly. This behavior within layers is intrinsically related to variations in soil bulk density that, over time, decreased in surface layers but increased in deeper depth.

\section{Table 4}

Significant interactions between duration of soil tillage prior to sampling and machine traffic in relation to soil organic carbon (SOC), total porosity (Pt), macroporosity (Ma), microporosity (Mi), bulk density (BD) and saturated hydraulic conductivity (Ks) in the three soil layers.

\begin{tabular}{|c|c|c|c|c|c|c|}
\hline Property & Traffic & $\mathrm{NTS}_{0.2}$ & NTS $_{1.5}$ & $\mathrm{NTS}_{3.5}$ & $\mathrm{NTS}_{5}$ & $\mathrm{NTS}_{14}$ \\
\hline \multicolumn{7}{|c|}{$0-7 \mathrm{~cm}$ soil layer } \\
\hline \multirow{2}{*}{ SOC (\%) } & Without & $1.9 \mathrm{a} \mathrm{BC}^{*}$ & 1.9 a C & 1.9 a C & 2.3 a A & $2.1 \mathrm{a} \mathrm{AB}$ \\
\hline & With & 2.0 a A & 1.6 b B & 1.6 b B & $2.1 \mathrm{~b} \mathrm{~A}$ & 2.1 a A \\
\hline \multicolumn{7}{|c|}{$7-14 \mathrm{~cm}$ soil layer } \\
\hline \multirow[t]{2}{*}{ SOC (\%) } & Without & 1.7 a BC & 2.0 a $\mathrm{A}$ & 1.9 a $\mathrm{AB}$ & 1.6 a BC & 1.6 a C \\
\hline & With & 1.6 a A & $1.7 \mathrm{~b} \mathrm{~A}$ & $1.7 \mathrm{~b} \mathrm{~A}$ & 1.5 a A & 1.7 a A \\
\hline \multirow[t]{2}{*}{$\mathrm{Pt}\left(\mathrm{cm}^{3} \mathrm{~cm}^{-3}\right)$} & Without & 0.66 a A & 0.56 a B & 0.47 a C & 0.51 a BC & 0.47 a C \\
\hline & With & $0.54 \mathrm{~b} \mathrm{~A}$ & $0.47 \mathrm{~b} \mathrm{~B}$ & 0.47 a B & 0.46 b B & 0.48 a B \\
\hline \multirow{2}{*}{$\begin{array}{l}\text { Ma } \\
\qquad\left(\mathrm{cm}^{3} \mathrm{~cm}^{-3}\right)\end{array}$} & Without & 0.32 a $A$ & 0.21 a B & 0.12 a $C$ & 0.13 a $C$ & 0.10 a C \\
\hline & With & $0.22 \mathrm{~b}$ & 0.12 b B & 0.11 a B & 0.11 a $B$ & 0.11 a $B$ \\
\hline \multicolumn{7}{|c|}{$14-21 \mathrm{~cm}$ soil layer } \\
\hline \multirow{2}{*}{$\begin{array}{l}\text { Ma } \\
\qquad\left(\mathrm{cm}^{3} \mathrm{~cm}^{-3}\right)\end{array}$} & Without & 0.13 a $\mathrm{A}$ & $0.13 \mathrm{~b} \mathrm{~A}$ & 0.14 a A & 0.10 a $\mathrm{A}$ & 0.10 a $\mathrm{A}$ \\
\hline & With & 0.17 a A & 0.15 a $\mathrm{AB}$ & $0.09 \mathrm{~b} B C$ & 0.16 a $\mathrm{AB}$ & 0.08 a C \\
\hline \multirow[t]{2}{*}{$\operatorname{Mi}\left(\mathrm{cm}^{3} \mathrm{~cm}^{-3}\right)$} & Without & 0.36 a B & 0.36 a B & 0.37 a $B$ & $0.38 \mathrm{a} \mathrm{AB}$ & 0.40 a A \\
\hline & With & 0.35 a C & 0.36 a BC & 0.38 a $\mathrm{AB}$ & 0.35 b C & 0.39 a $A$ \\
\hline \multirow[t]{2}{*}{$\mathrm{BD}\left(\mathrm{g} \mathrm{cm}^{3}\right)$} & Without & $7.1 \mathrm{~b} \mathrm{~A}$ & 4.5 a $\mathrm{AB}$ & $3.7 \mathrm{a} A B$ & 3.2 a $A B$ & 1.0 a B \\
\hline & With & 14.2 a A & 5.4 a B & 1.5 a B & 6.3 a B & 1.2 a B \\
\hline \multirow[t]{2}{*}{$\mathrm{Ks}\left(\mathrm{cm} \mathrm{h}^{-1}\right)$} & Without & $7.1 \mathrm{~b}$ A & $4.5 \mathrm{a} \mathrm{AB}$ & 3.7 a $\mathrm{AB}$ & $3.2 \mathrm{a} \mathrm{AB}$ & 1.0 a B \\
\hline & With & 14.2 a A & 5.4 a B & 1.5 a B & 6.3 a B & 1.2 a B \\
\hline
\end{tabular}

$\mathrm{NTS}_{0.2}$-soil disturbance in the no-tillage system at 2 months prior to soil sampling; $\mathrm{NTS}_{1.5}$-soil disturbance in the no-tillage system 1.5 years prior to soil sampling; NTS $_{3.5}$-soil disturbance in the no-tillage system 3.5 years prior to soil sampling $\mathrm{NTS}_{5}$-soil disturbance in the no-tillage system 5 years prior to soil sampling and $\mathrm{NTS}_{14}-$ no soil disturbance in the no-tillage system for 14 years prior to sampling. CV-coefficient of variation. ns-not significant.

Means for a given property followed by the same small letter or capital letter, respectively in a given column or line, do not differ by Tukey test $(p<0.05)$. 


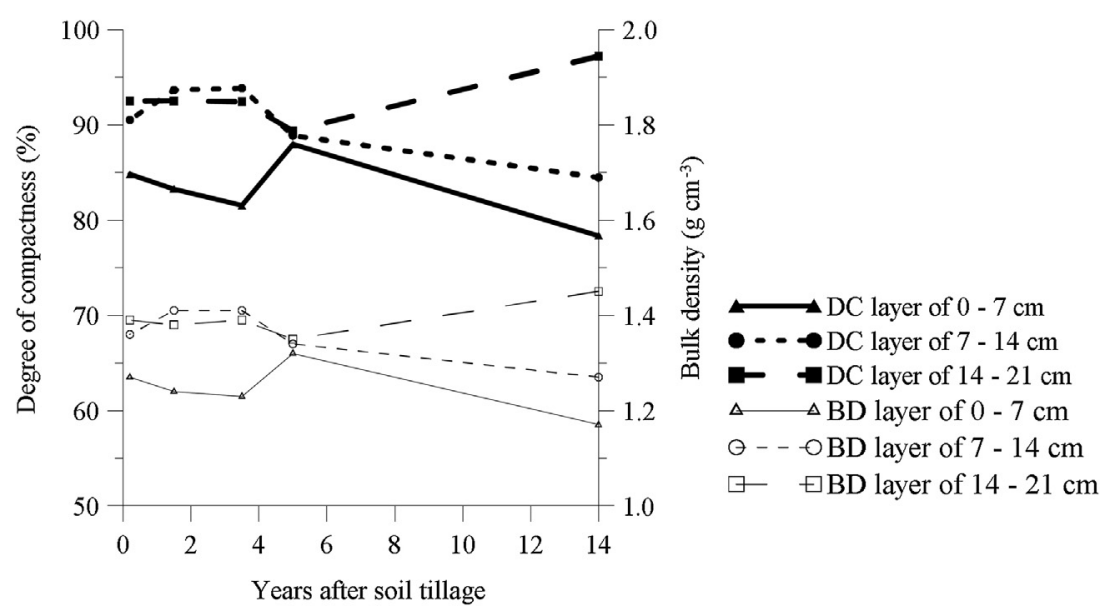

Fig. 1. Degree-of-compactness (DC) and bulk density (BD) for three soil layers and different times after plowing for deploying no-tillage system.

Soil Ma and Mi changed over time due to soil structural changes, with an initial increase in Ma and decrease in Mi (Table 3). However, after 14 years of no-tillage Ma reduced and Mi increased, providing conditions required for improved soil water retention, as shown latter in this paper. Soil Pt and Ma were high in intermediate soil layer, where non-trafficked soil showed greater Pt and Ma (Table 3). Regardless of machine traffic, $\mathrm{NTS}_{0.2}$ had the greatest values of Pt and Ma. In the $14-21 \mathrm{~cm}$ soil layer, $\mathrm{NTS}_{0.2}$ and NTS 1.5 showed greater Ma, contrary to $\mathrm{NTS}_{14}$ that regardless of machine traffic had greatest Mi and smallest Ma. Soil Ks had only significant differences in the deepest soil layer, with greater values for soil without traffic. In trafficked soil, $\mathrm{NTS}_{0.2}$ showed greatest Ks that differed significantly from other soil conditions. Without machine traffic $\mathrm{NTS}_{0.2}$ had the greatest Ks, but only differed statistically from NTS ${ }_{14}$ with smallest Ks associated to low Ma.

Soil without machine traffic after two months since last tillage $\left(\mathrm{NTS}_{0}\right)$ had highest water drainage at high (less negative) matric potentials. The reverse was obtained in $\mathrm{NTS}_{14}$, which initially showed low drainage and this soil retained more water compared to other soil conditions (Fig. 2). Saturated water content ranged from $0.51 \mathrm{~cm}^{3} \mathrm{~cm}^{-3}$ in $\mathrm{NTS}_{14}$ and NTS 1.5 to $0.58 \mathrm{~cm}^{3} \mathrm{~cm}^{-3}$ in $\mathrm{NTS}_{5}$.

For trafficked soils, however, $\mathrm{NTS}_{0}$ and $\mathrm{NTS}_{14}$ exhibited the greatest saturated water content in the surface layer, and in $\mathrm{NTS}_{0}$ a high air capacity (at $-6 \mathrm{kPa}$ ), indicating lower water retention. The same trend arose in $7-14 \mathrm{~cm}$ soil layer, as $\mathrm{NTS}_{0}$ showed greatest saturation water content, followed by $\mathrm{NTS}_{14}$. Similarly, in $\mathrm{NTS}_{0.2}$ there existed a rapid water drainage at $-0.1-\mathrm{kPa}$ matric potential. For $\mathrm{NTS}_{1.5}, \mathrm{NTS}_{3.5}$ and $\mathrm{NTS}_{5}$, high water retention was observed when applying more negative matric potential. In this layer, NTS 14 soil revealed the greatest water retention when subjected to matric potentials smaller or equal to $-6 \mathrm{kPa}$.

All soil conditions showed approximately the same saturated soil water content in the $14-21 \mathrm{~cm}$ soil layer, although $\mathrm{NTS}_{0.2}$ soil had larger water drainage with increased matric potential. This result implies less water retention, contrary to $\mathrm{NTS}_{14}$ that had greater water retention than other soil conditions even at lower (more negative) matric potential. However, over time plant available water increased particularly in the surface layer (0$7 \mathrm{~cm}$ ) (Fig. 3). In subsoil layers (7-14 and 14-21 cm) the amount of available water was equal to or slightly higher than it was at the start of the experiment.

\subsection{Intensity properties}

Soil precompression stress $\left(\sigma_{\mathrm{p}}\right)$ was similar in all layers, with higher average values for 1.5 years after soil tillage (Fig. 4).
Fourteen years after tillage, however, $\sigma_{\mathrm{p}}$ decreased and reached levels similar to sites under recent tillage management. Soil compressibility coefficient (Cc) gradually declined over time, reaching values slightly below those after tillage in both upper layers (0-7 and 7-14 cm), and above those in the deeper soil layer $(14-21 \mathrm{~cm})$.

Soil saturated hydraulic conductivity (Ks) was greatest in the 0$7 \mathrm{~cm}$ soil layer of $\mathrm{NTS}_{0.2}$ (Table 3 ). In the intermediate layer (7$14 \mathrm{~cm}), \mathrm{NTS}_{0.2}, \mathrm{NTS}_{1.5}$ and $\mathrm{NTS}_{14}$ had significantly higher Ks values in comparison with other soil conditions. The effect of soil tillage was also observed in the $14-21 \mathrm{~cm}$ soil layer where $\mathrm{NTS}_{0.2}$ had greatest Ks; $\mathrm{NTS}_{1.5}, \mathrm{NTS}_{3.5}$ and $\mathrm{NTS}_{5}$ showed intermediate values. $\mathrm{NTS}_{14}$ had smallest Ks and porosity values which statistically differed from other soil conditions.

Soil air permeability (Ka) for soil without machine traffic was greatest in $\mathrm{NTS}_{0} 0-7$ and $7-14 \mathrm{~cm}$ soil depths for all matric potentials, which is in agreement with the observed high Pt and Ma and possibly greater pore continuity. Similarly, in trafficked soil and for above mentioned soil layers, $\mathrm{NTS}_{0}$ and $\mathrm{NTS}_{14}$ provided greatest Ka values (Fig. 5), whereas smallest Ka was in NTS N.5 $_{1.5}$ and $\mathrm{NTS}_{3.5}$ for all soil layers, regardless of machine traffic. The increased Ka with decreased matric potential under all soil conditions and soil layers may be linked to drainage processes and consequent increasing air-filled porosity.

\section{Discussion}

\subsection{Capacity properties}

Soil organic matter content is linked to soil structural quality (Horn and Peth, 2009). Any agricultural practice that increases soil organic carbon content will contribute to stabilizing pore structure and increase the soil's capacity to withstand loads from machine traffic without collapsing (Horn et al., 2003; Bhattacharyya et al., 2006).

Reduction in soil carbon content in recently-tilled soil is due to increased organic matter mineralization rate. Tillage promotes soil aggregate breakdown, allowing for oxygen inflow and thereby stimulating microbial decomposition and loss of carbon as $\mathrm{CO}_{2}$ (Campbell et al., 2001). Organic matter mineralization from surface layers might be responsible for soil organic carbon decrease observed with time in $\mathrm{NTS}_{1.5}$ and $\mathrm{NTS}_{3.5}$ soil when compared to the initial content (2.0\%). This is also related to the action of implements (mainly disking) used in soil tillage, which causes the grinding of plant residues and increases its surface area during the incorporation process into the soil. In total these processes 
Layer of $0-7 \mathrm{~cm}$
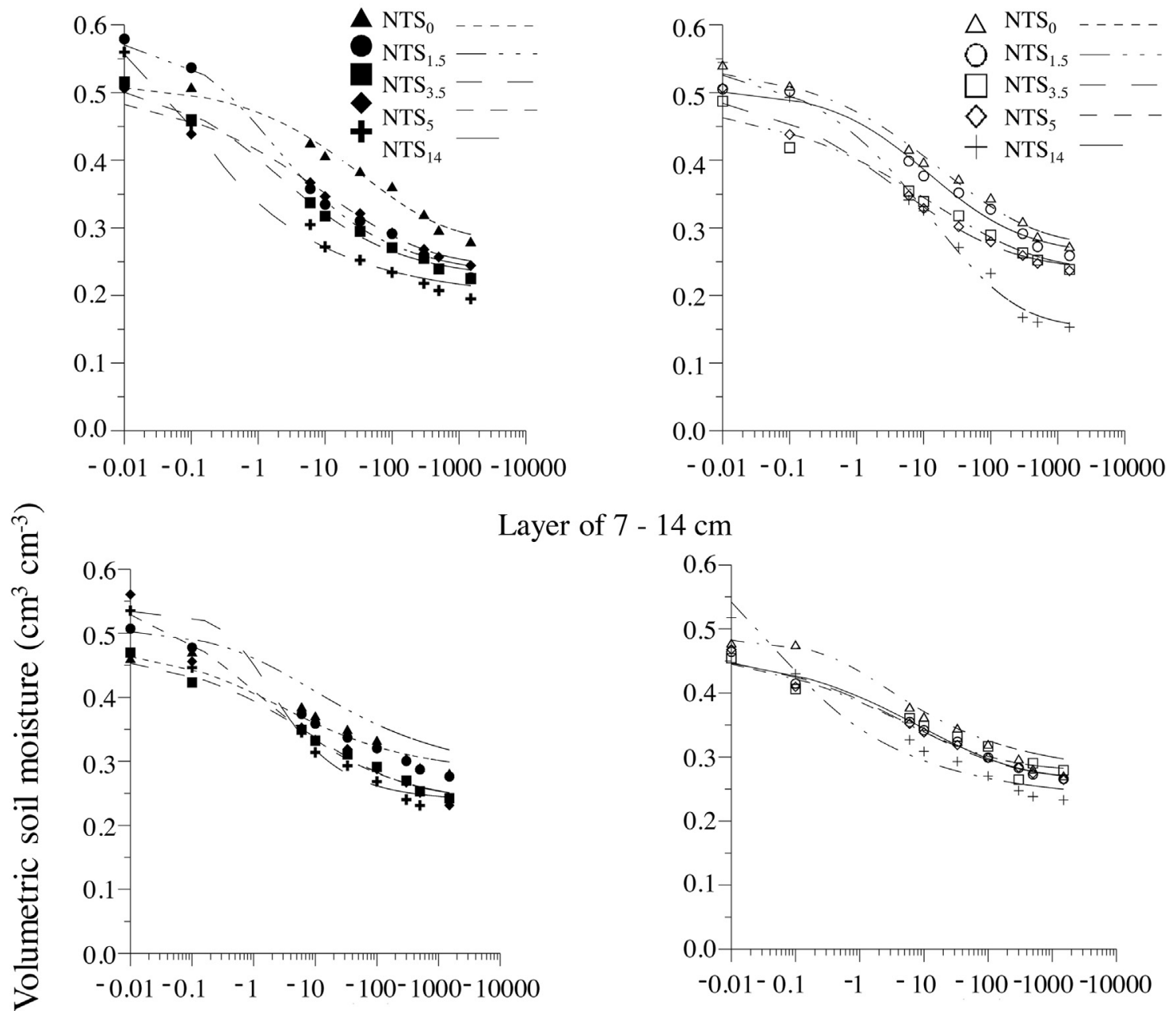

Layer of $7-14 \mathrm{~cm}$

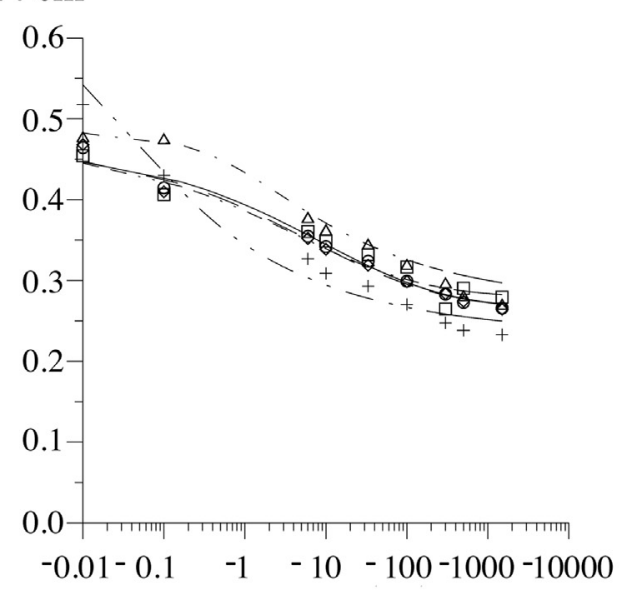

Layer of $14-21 \mathrm{~cm}$
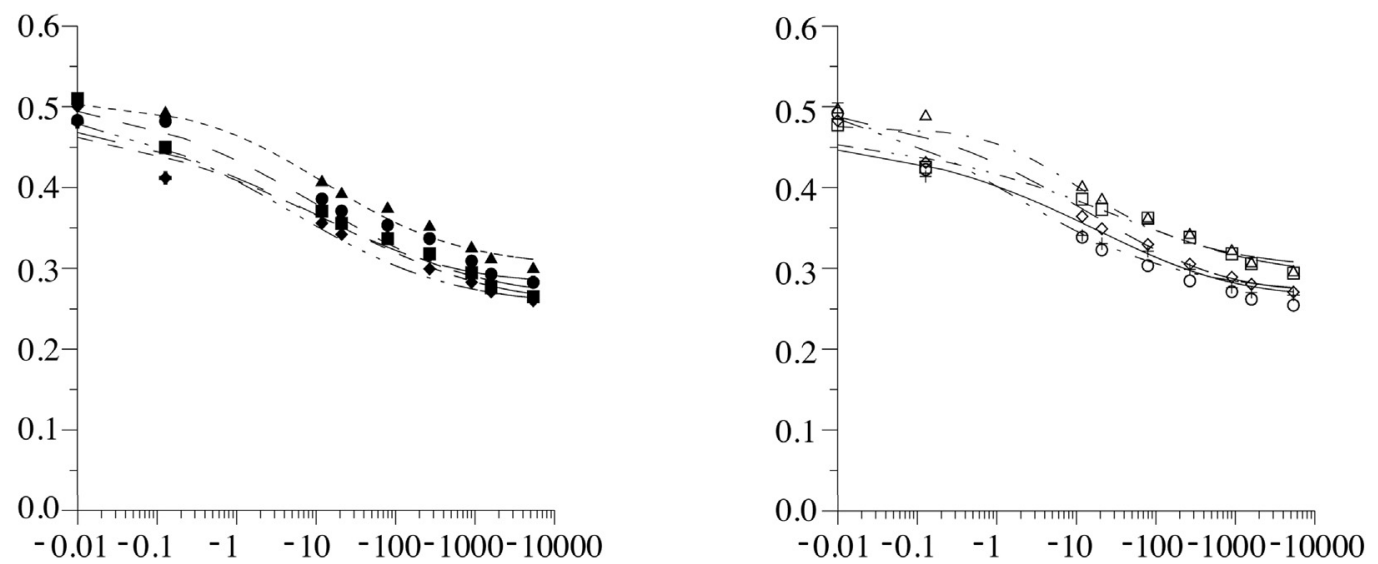

Matric Potential $(\mathrm{kPa})$

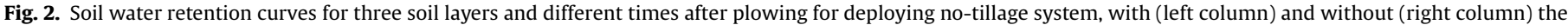
effects of farm machinery traffic.

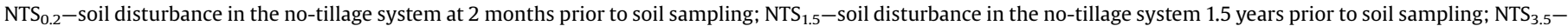

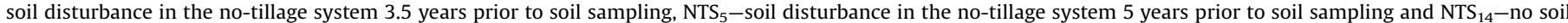
disturbance in the no-tillage system for 14 years prior to sampling. 


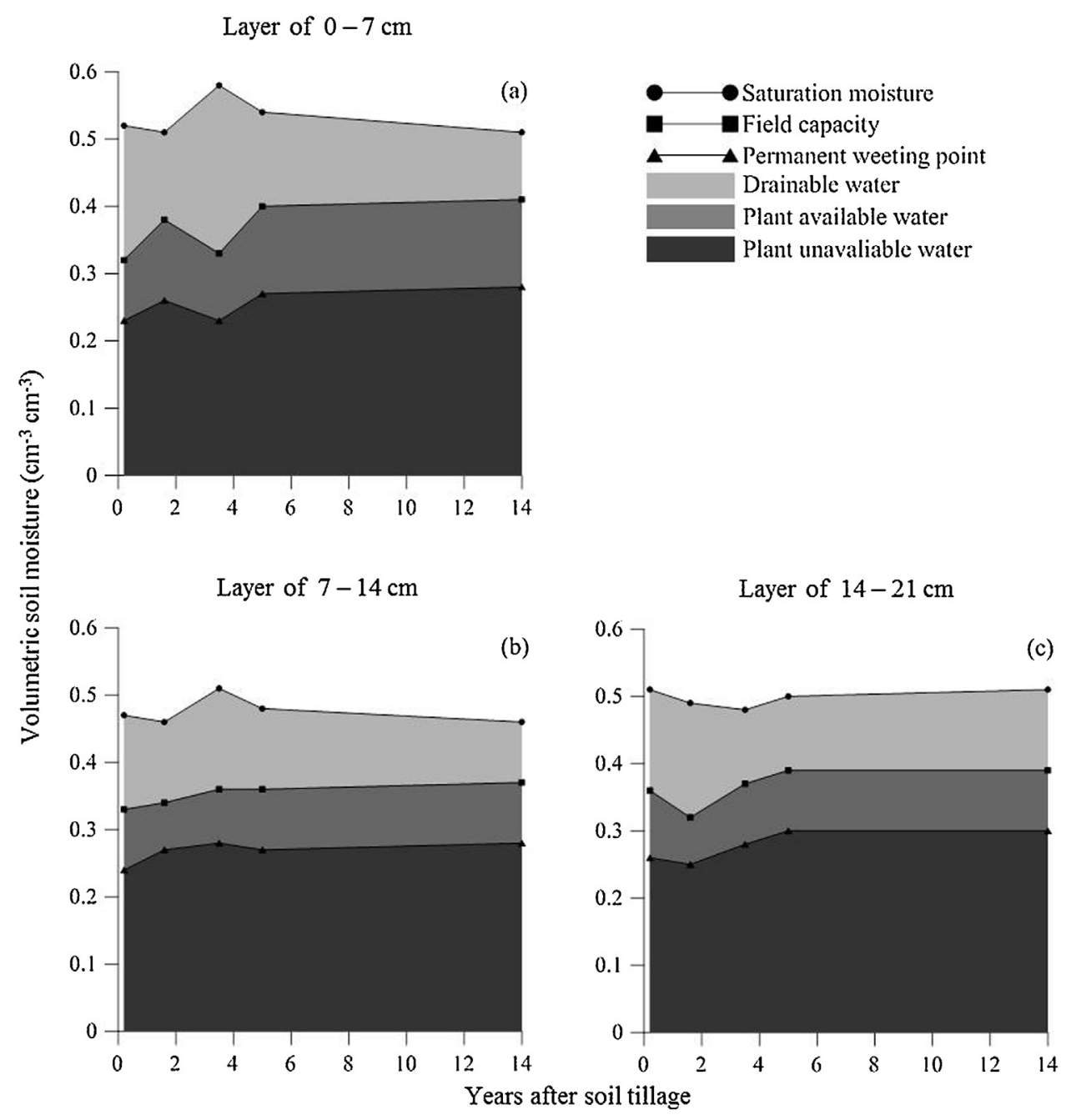

Fig. 3. Plant available water for three soil layers and different times after plowing for deploying no-tillage system.

favor the plant residue decomposition (Kihara et al., 2012), compared to mulch on soil surface (Lal, 2009).

With increased time of no-tillage history, soil organic carbon content increase evidences the beneficial effects of no-tillage. Lal (2009) and Šimon et al. (2009) pointed out some advantageous effects of no-tillage such as maintenance of plant residues on soil surface and reduction in $\mathrm{CO}_{2}$ emission, thus increasing soil carbon stock. The SOC reduction in the soil surface layer may be followed by an increase in carbon in deeper soil layers, depending on soil disturbance and residue incorporation into soil (Lal, 2009).

Trafficked soil revealed lower organic carbon content in surface layers possibly due to high compaction that hinders plant growth and root development (Chen and Weil, 2011), which results in a smaller input of organic materials. Thus, soil wheeling indirectly affected organic matter contents by providing unfavorable soil physical conditions for crop growth and biomass addition to soil (Hamza and Anderson, 2005). Stressed stunted plant growth and development observed is a direct result of poor root growth and reduced water availability in compacted soil, resulting in low input of organic material to soil surface and hence reduction of soil organic carbon with time (Hamza and Anderson, 2005). In the subsurface layer $(14-21 \mathrm{~cm})$ of our study there was no significant effect of machine traffic on organic carbon, probably because the applied mechanical stresses did not reach deeper soil layers and compaction did not limit root growth and biological activity.
Soil degree-of-compactness decrease over time in surface layers is a possible evidence that NTS may provide favorable conditions for plant growth even without tillage and contributes to soil aggregation and improves soil structure (Horn et al., 1995; da Veiga et al., 2007), thus resisting to compaction loads applied on soil (Cavalieri et al., 2009). It is noteworthy that at greater depths, as in the $14-21 \mathrm{~cm}$ layer, added effects of roots and other living organisms is not pronounced, being restricted mainly to surface layers (da Veiga et al., 2007). However, even a minor increase in root surfaces enhances the apparent soil cohesion and, if we furthermore include the intensely increased soil strength based on the very pronounced tensile root strength, we may relate the stronger soil conditions to the overall improved structure formation and soil strengthening by hydraulic and biological processes (Wu and Watson, 1988; Paterson et al., 2007; Czarnes et al., 1999; Trükmann, 2010). Therefore, even if only very few small or fine roots can be detected they may help to improve the soil strength to a great extent. Amelioration of deeper and more compacted soil layers, as detected in our soils especially under controlled traffic conditions with a trend of increasing bulk density and degree-of-compactness, requires additional hydraulic and biological processes. A mere breakdown promoted by deep tillage would enhance load transmission to deeper soil layers.

Greatest values of soil total porosity and macro-porosity and smallest soil bulk density in surface layer of $\mathrm{NTS}_{0}$ are due to recent 

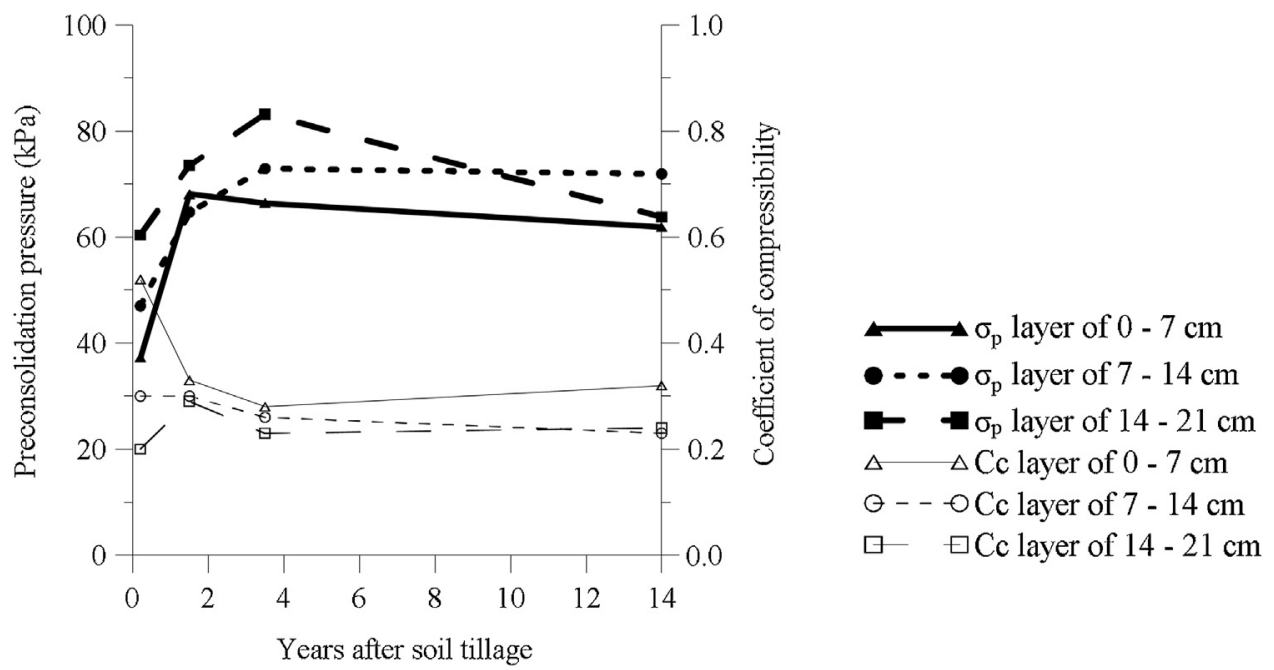

Fig. 4. Precompression stress $\left(\sigma_{\mathrm{p}}\right)$ and compressibility coefficient $(\mathrm{Cc})$ for three soil layers and different times after plowing for deploying no-tillage system.

soil tillage that disturbed soil structure (da Veiga et al., 2007). With increasing time of no-tillage, there was a tendency of increasing soil bulk density until reaching a quasi-stable value after 3.55 years of NTS adoption. These effects on soil density and porosity may result from natural rearrangement of soil particles and aggregates, and from loads exerted during traffic by agricultural machines and implements, especially under inadequate soil moisture conditions (Botta et al., 2011). Furthermore, cropping systems with crop rotations contribute to the rearrangement of soil particles into more stable aggregates (Wohlenberg et al., 2004). Soil biota and especially plant roots play a major role in structure (pore formation, particle aggregation, and exudates release) (Kihara et al., 2012). In our experiment, the effects resulted from 4.9-Mg tractor wheeling and greater effect on soil density and macroporosity would be expected if heavier load machines are used for field operations.

Decrease in soil bulk density after 14 years of continuous NTS may indicate an intense rearrangement of soil particles during long-term repeated swelling/shrinking and biological processes, which allow reaching the final stage of smallest free entropy, as proposed by Addiscott (1995). As a consequence of an increased number of particle to particle contacts with maximum of particle area in parallel, even the improved soil physical quality condition can withstand external forces at a lower bulk density. Furthermore, an enhanced biological activity results in the formation of more vertically oriented, major stress equilibrated stronger pores, additionally fixed by exudates, which reduce soil deformation risks but provide a better plant-root growth system (Hartge and Horn, 2009; Chen and Weil, 2011). Lal (2009) and Šimon et al. (2009) state that soil bulk density under NTS may decrease over time mainly due to increase in organic matter content in the surface layer, which enhances aggregation and stabilization of soil structure.

Greatest macroporosity compared to other tillage systems in $\mathrm{NTS}_{0.2}$, regardless of machine traffic, demonstrates the effectiveness of soil tillage to increase the total porosity and macroporosity. This is, however, a transient condition. With time, the volume decreases with soil particle re-arrangement and pressure applied by growing plant roots (Grzesiak et al., 2012) or by machine traffic (Chen and Weil, 2011).

High water retention at saturation ( $0 \mathrm{kPa}$ matric potential) in surface layers (from 0 to $14 \mathrm{~cm}$ ) in $\mathrm{NTS}_{0.2}$ soil without machine traffic contrasted to a rapid water drainage with decreasing matric potential. This is a classic response to soil disturbance which degrades soil structure, thus resulting in increased soil total porosity and macroporosity (pores drained at $6 \mathrm{kPa}$ ) at the expense of microporosity (pores not drained at $6 \mathrm{kPa}$ ) (da Veiga et al., 2007), and hence increased water retention near saturated conditions. This behavior favors drainage and rapid reduction in water retained by soil at less negative matric potentials (Fabrizzi et al., 2005). By contrast, NTS $_{14}$ (longest time without soil tillage) is characterized by slow drainage and less water retention initially at higher matric potentials ( 0 to $-10 \mathrm{kPa}$ ), but more water retention at more negative matric potentials (less than $-10 \mathrm{kPa}$ ), which shows the importance of maintaining soil structure and pore structure conditions (da Veiga et al., 2007) in addition to increased soil organic carbon content (Campbell et al., 2001; Hazarika et al., 2009) as observed in our study. Thus, in practical terms there is less water loss with the onset of soil drying and better water retention at higher (less negative) potentials, resulting in higher water availability (water retained between -10 and $-1500 \mathrm{kPa}$ ) to plants.

The fact that the water retention curve in the $14-21 \mathrm{~cm}$ soil layer was similar for all soil conditions with also approximately the same saturated soil water content indicates tillage or no-tillage did not significantly affect this layer, thus showing for machine traffic of traditionally-used tractors (medium loading) in southern Brazil soil compression is confined to surface layers. These means plowing turned around the soil volume, but the loosening and volume expansion is of short duration.

Plant available water increases over time, particularly in surface layer $(0-7 \mathrm{~cm})$, due to soil structure improvement mentioned above. Bhattacharyya et al. (2006) and Fabrizzi et al. (2005) also observed more water with consolidation of no-tillage system. Fabrizzi et al. (2005) added that increased water holding capacity was significantly important during droughts, ensuring water supply to corn, resulting in higher yield than in conventionallytilled soil. In subsurface layers $(7-14$ and $14-21 \mathrm{~cm}$ ) the effect was less pronounced, probably due to higher root and nutrient concentration in surface layers. Thus, absence of soil disturbance in no-tillage soil, in controlled traffic conditions, does not adversely affect water storage and availability, and even after 14 years of NTS adoption tillage is not a necessary practice, provided roots and soil organisms contribute to an equilibrated pore-size distribution for water and air retention and flow in the soil. 
Layer of $0-7 \mathrm{~cm}$
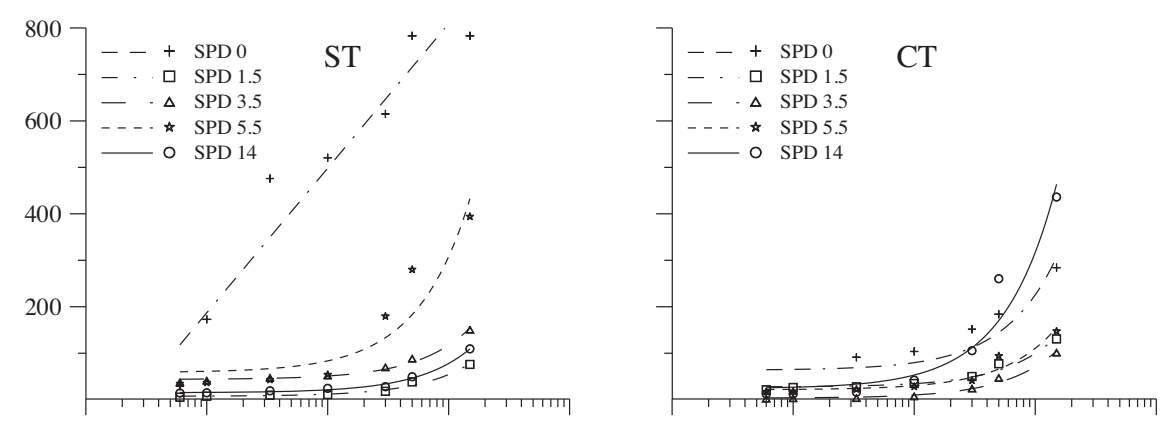

Layer of $7-14 \mathrm{~cm}$
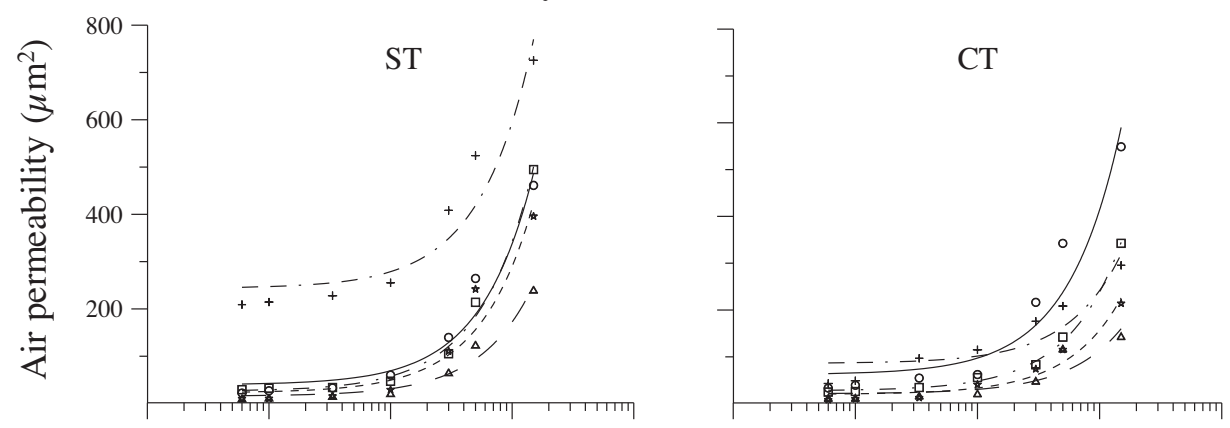

Layer of $14-21 \mathrm{~cm}$
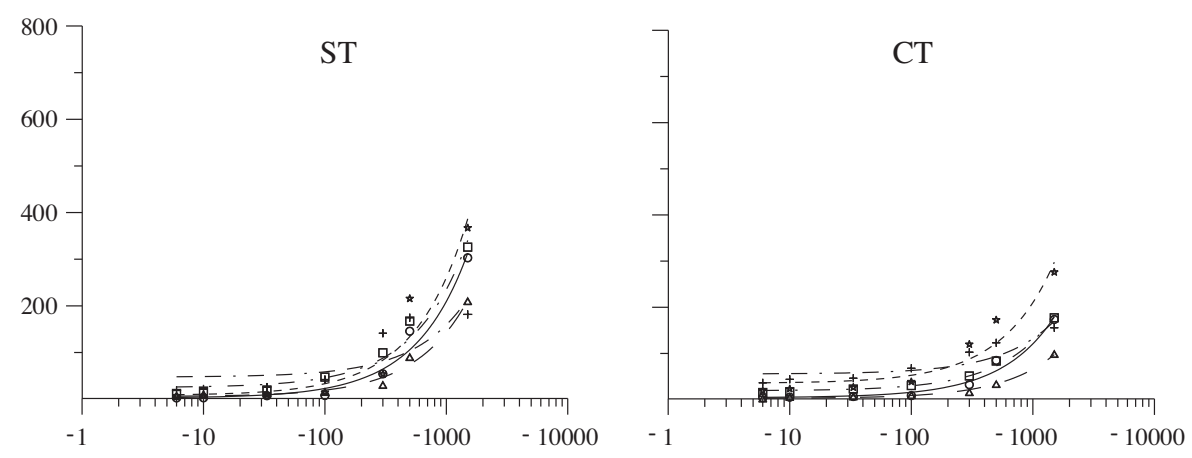

Matric potential $(\mathrm{kPa})$

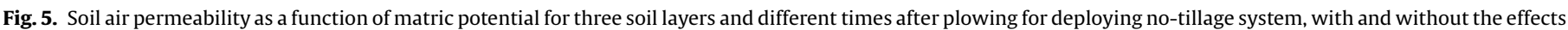
of farm machinery traffic.

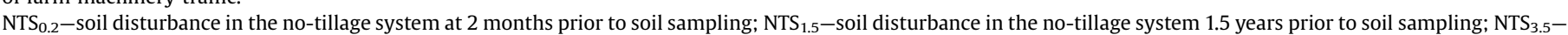

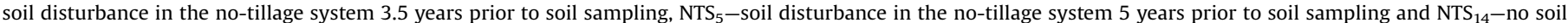
disturbance in the no-tillage system for 14 years prior to sampling.

\subsection{Intensity properties}

Changes in physical properties caused by soil tillage and trafficking are time-dependent, and such changes differ depending on the parameter type. Horn (2004) proved that soil mechanical strength parameters, like the precompression stress, increased the more the smaller the tillage intensity was and the less pronounced the wheeling intensities were. He explained these effects with the necessary rearrangement of particles, which must reach the final stage of smallest entropy, which indeed takes time.

The increase in soil precompression stress immediately after soil tillage is related to soil disruption of the massive, less porous structure (da Veiga et al., 2007), as evidenced by the high bulk density immediately after tillage. After 14 years since last tillage, soil bulk density decreased and porosity increased, with a consequent reduction in precompression stress, which might have possibly occurred but this would underline that a new equilibrium was still not reached.

Although reducing precompression stress means greater susceptibility to compression due to lower soil load bearing capacity (Vogelmann et al., 2012b), this reduction may however translate into better soil environment for root growth (Horn et al., 1995; Rosa et al., 2008) and soil aeration (Mordhorst et al., 2012). Concerning the final stage of lowest free entropy, we define such stage as near steady-state as the "loosening" and improvement of soil ecological properties and functions can still be optimized both with respect to soil strength and soil functions. This stage expresses emerging properties (Nicolis and Prigogine, 1977) of the soil system.

When the applied load is greater than soil precompression stress (load bearing capacity), degradation can occur by changing pore structure with reduction in pore size and distorting pore 
geometry while often bulk density increases as well as the resistance to root penetration (Grzesiak et al., 2012). Moreover, such physical changes resulting from load application exceeding soil bearing capacity may affect soil water storage due to reduced infiltration capacity, total porosity and macroporosity, and increased microporosity. Even though micropores retain more water, it is under smaller matric potential and may be unavailable to plants (Fabrizzi et al., 2005).

As an indicator of soil deformation susceptibility (da Veiga et al., 2007; Vogelmann et al., 2012b; Braga et al., 2015), the soil compressibility index was greater after soil tillage. In general, higher values of the compressibility index were associated with lower values of soil bulk density which can be explained by the fact that this parameter defines the slope of the virgin compression load range, i.e., there was no former strengthening process involved. The tendency of decreasing compressibility index over time indicates that without tillage soil reconsolidation, based primarily on soil particles rearrangement by wetting-drying cycles and development of plant rooting system and soil organisms, may result in reduced soil susceptibility to compaction and therefore less additional deformation when high loads (higher than precompression stress) are applied to soil (da Veiga et al., 2007; Chen and Weil, 2011).

Soil organic matter (Braida et al., 2006, 2008) and crop mulch (Braida et al., 2006; Kaiser et al., 2013; Reichert et al., 2015c) exert a cushioning effect of traffic partially dissipating the impact energy applied to soil by machines. Krzic et al. (2004) showed, for forest soils varying in texture ( $12-87 \%$ sand, $9-76 \%$ silt, and $2-53 \%$ clay) and organic matter content (18-76 $\mathrm{g} \mathrm{kg}^{-1}$ total C), that an increase of $1 \%$ in organic carbon content reduces the maximum relative density by about $11 \%$ irrespective of soil texture. In our study there was a slight increase in the organic matter over time, especially in the surface layer, and wheeling was over a layer of mulch in NTS.

Soil saturated hydraulic conductivity increased with time of tillage type application even down to greater soil depths, even though soil bulk density did not differ between the various treatments. These effects make clear that soil management and time of application are the most important parameters, and that the greatest changes really are detectable and quantifiable using intensity rather than capacity properties. Greater soil saturated hydraulic conductivity, in intermediate soil layer $(7-14 \mathrm{~cm})$ for $\mathrm{NTS}_{0.2}, \mathrm{NTS}_{1.5}$ and $\mathrm{NTS}_{14}$, have different explanations since there are time-dependent effects. In $\mathrm{NTS}_{0}$ and $\mathrm{NTS}_{1.5}$ it may be due to recent soil tillage by ploughing and harrowing, resulting in increased soil pore volume and permeability, whilst in $\mathrm{NTS}_{14}$ high hydraulic conductivity resulted from soil structural aggregation and improved soil physical conditions by biological agents, mainly growing plant roots that contribute to creating pore continuity, and low macropore and high micropore volumes. No-tillage and total or partial conservation of plant residues (mulch) on soil surface are strategies for maintaining or improving soil physical properties and processes (Bernoux et al., 2006), as reduced bulk density (Cavalieri et al., 2009), soil erosion and runoff (Schäfer et al., 2001; Bonumá et al., 2013; Didoné et al., 2014), increased aggregate stability (Wohlenberg et al., 2004; Fabrizzi et al., 2005), and soil hydraulic conductivity (Abreu et al., 2004; Bhattacharyya et al., 2006).

Increasing air permeability as water matric potential decreased for all soil conditions is a result of water drainage in large pores, thereby indorsing the importance of air-filled porosity on air permeability. Møldrup et al. (2001) and Dane et al. (2011) found increasing air permeability as soil volumetric water content declined, and this response resulted from draining pores previously occupied by water and emptying of irregularly-shaped pores which could retain water, thus increasing the continuity of smaller pores. Horn and Smucker (2005) and Vogelmann et al. (2012a) asserted soils with high macropore volume drain more water at high matric potentials, resulting in increased air space and adequate soil aeration. This explains high values of air permeability found in recently mobilized soil, where soil disturbance promoted breakdown of original soil structure and allowed for larger-pores (macropores) formation.

Soil consolidation and biological pore-formation or biological chiseling (Abreu et al., 2004) are responsible for pore continuity in the soil profile, and thereby increasing water conductivity and air permeability. Greatest blocked porosity in surface layers of $\mathrm{NTS}_{0.2}$ and $\mathrm{NTS}_{1.5}$, regardless of trafficked and non-trafficked soil, are possibly due to short time between soil tillage and soil sampling in these conditions (Table 5). With time, there was a clear reduction in obstructed porosity, irrespective of machine traffic. $\mathrm{NTS}_{3.5}$ soil is apparently undergoing changes, and clogging of soil pores is no longer apparent when compared to soil initial condition. Therefore, with time there is always soil structural modifications and biological activity, which improves soil air permeability even without changes in bulk density or total pore volume, since bulk density is mass per volume but the value does not tell you where the mass in the volume is located. Growing roots compress the soil

Table 5

Regression parameters ( $M$ and $N$ ) and obstructed porosity $\left(\varepsilon_{\mathrm{b}}\right)$ of an Oxisol in the three soil layers under different soil management, with and without machine traffic.

\begin{tabular}{|c|c|c|c|c|}
\hline Soil management & $\log M$ & $N$ & $\varepsilon_{\mathrm{b}}(\mathrm{vol} . \%)$ & $R^{2}$ \\
\hline \multicolumn{5}{|c|}{$0-7 \mathrm{~cm}$ soil layer-without traffic } \\
\hline $\mathrm{NTS}_{0}$ & 7.17 & 12.18 & 25.79 & 0.92 \\
\hline $\mathrm{NTS}_{1.5}$ & -1.78 & -5.62 & 48.29 & 0.89 \\
\hline $\mathrm{NTS}_{3.5}$ & 3.57 & 3.26 & 8.04 & 0.85 \\
\hline $\mathrm{NTS}_{5}$ & 4.92 & 5.32 & 11.92 & 0.87 \\
\hline $\mathrm{NTS}_{14}$ & 2.98 & 2.02 & 3.35 & 0.81 \\
\hline \multicolumn{5}{|c|}{$7-14 \mathrm{~cm}$ soil layer-without traffic } \\
\hline $\mathrm{NTS}_{0}$ & 3.88 & 2.52 & 2.89 & 0.70 \\
\hline $\mathrm{NTS}_{1.5}$ & 5.44 & 6.16 & 13.11 & 0.87 \\
\hline $\mathrm{NTS}_{3.5}$ & 5.15 & 4.73 & 8.12 & 0.86 \\
\hline $\mathrm{NTS}_{5}$ & 6.65 & 6.75 & 10.32 & 0.86 \\
\hline $\mathrm{NTS}_{14}$ & 5.21 & 3.85 & 4.44 & 0.87 \\
\hline \multicolumn{5}{|c|}{$14-21 \mathrm{~cm}$ soil layer-without traffic } \\
\hline $\mathrm{NTS}_{0}$ & 5.56 & 0.91 & 0.91 & 0.91 \\
\hline $\mathrm{NTS}_{1.5}$ & 6.14 & 5.95 & 9.32 & 0.96 \\
\hline $\mathrm{NTS}_{3.5}$ & 5.61 & 5.96 & 11.43 & 0.86 \\
\hline $\mathrm{NTS}_{5}$ & 5.97 & 5.29 & 7.43 & 0.85 \\
\hline $\mathrm{NTS}_{14}$ & 6.74 & 6.58 & 9.45 & 0.93 \\
\hline \multicolumn{5}{|c|}{$0-7 \mathrm{~cm}$ soil layer-with traffic } \\
\hline $\mathrm{NTS}_{0}$ & 6.70 & 5.73 & 31.88 & 0.90 \\
\hline $\mathrm{NTS}_{1.5}$ & 3.78 & 4.12 & 18.10 & 0.85 \\
\hline $\mathrm{NTS}_{3.5}$ & 4.24 & 8.54 & 5.09 & 0.78 \\
\hline $\mathrm{NTS}_{5}$ & 5.30 & 2.55 & 16.30 & 0.82 \\
\hline $\mathrm{NTS}_{14}$ & 4.45 & 5.19 & 8.27 & 0.85 \\
\hline \multicolumn{5}{|c|}{$7-14 \mathrm{~cm}$ soil layer-with traffic } \\
\hline $\mathrm{NTS}_{0}$ & 5.23 & 5.11 & 4.45 & 0.82 \\
\hline $\mathrm{NTS}_{1.5}$ & 7.81 & 4.63 & 11.13 & 0.84 \\
\hline $\mathrm{NTS}_{3.5}$ & 3.43 & 3.28 & 5.29 & 0.91 \\
\hline $\mathrm{NTS}_{5}$ & 8.72 & 8.49 & 7.52 & 0.83 \\
\hline $\mathrm{NTS}_{14}$ & 9.50 & 2.52 & 6.85 & 0.81 \\
\hline \multicolumn{5}{|c|}{$14-21 \mathrm{~cm}$ soil layer-with traffic } \\
\hline $\mathrm{NTS}_{0}$ & 3.56 & 3.24 & 5.17 & 0.81 \\
\hline $\mathrm{NTS}_{1.5}$ & 8.14 & 4.53 & 7.47 & 0.91 \\
\hline $\mathrm{NTS}_{3.5}$ & 3.61 & 7.83 & 12.26 & 0.90 \\
\hline $\mathrm{NTS}_{5}$ & 3.97 & 4.35 & 4.75 & 0.95 \\
\hline $\mathrm{NTS}_{14}$ & 4.74 & 4.38 & 8.83 & 0.90 \\
\hline
\end{tabular}

$\mathrm{NTS}_{0.2}-$ soil disturbance in the no-tillage system at 2 months prior to soil sampling; $\mathrm{NTS}_{1.5}$-soil disturbance in the no-tillage system 1.5 years prior to soil sampling; $\mathrm{NTS}_{3.5}$-soil disturbance in the no-tillage system 3.5 years prior to soil sampling, $\mathrm{NTS}_{5}-$ soil disturbance in the no-tillage system 5 years prior to soil sampling and $\mathrm{NTS}_{14}-$ no soil disturbance in the no-tillage system for 14 years prior to sampling. 
in regions adjacent to root walls and dead roots constitute substrate for microorganisms (Bhattacharyya et al., 2006), thus shaping a rigid, continuous porous structure responsible for air and water flow in the soil (Møldrup et al., 2001; Dane et al., 2011). Soils with air permeability as little as $1 \mu \mathrm{m}^{2}$ may be considered as impermeable; therefore, the intercept of the abscissa may be regarded as an estimate of blocked air-filled pore space (blocked porosity $\varepsilon_{\mathrm{b}}$ ), which does not take part in the transport of air by convection (Ball et al., 1988). For long-term no-till soils, Mentges et al. (2015) concluded intensity properties are better descriptors of the time-variable aeration status. They observed soil granulometry, moisture, and structure (soil deformation) affected aeration capacity and intensity properties. Regardless of soil wetness, soil compaction reduced air-filled porosity, pore continuity, and air permeability, where the increase in permeability as soil moisture decreases is greatest in sandy-textured soil compared with clay-textured soils.

\subsection{A framework for the evolution of capacity and intensity properties under no-tillage}

We propose a framework for the evolution of capacity and intensity properties under no-tillage with and without farm machinery traffic. The framework (Fig. 6) considers the capacity
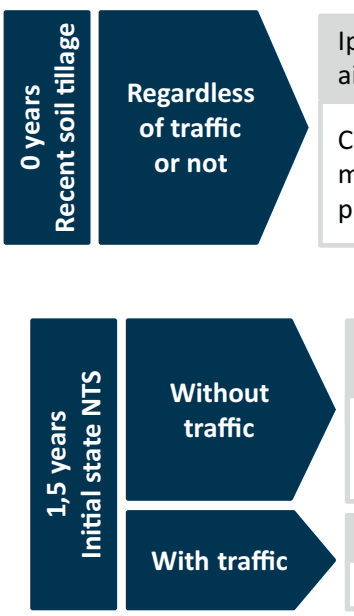

With traffic
Ip: Compressibility coefficient (Cc), saturated hydraulic conductivity (Ks) and air permeability (Ka) increase due recent tillage.

$\mathrm{Cp}$ : Soil organic carbon (SOC) is not affected. Total porosity (Tp) and macroporosity (Ma) increase; bulk density (BD), microporosity (Mi) and plant availabe water (Paw) decrease.

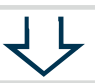

Ip: Cc decreases; pre-compression stress $\left(\sigma_{p}\right)$ increases due natural soil reconsolidation. Ks and Ka have the highest values.

$\mathrm{Cp}$ : SOC slightly increases due crop residue mineralization; degree of compactness (Dc) is not affected; BD, water retention ( $\mathrm{Wr}$ ) and Paw decrease; Tp and Ma increases.

Ip: Ks and Ka are not affected by traffic.

$\mathrm{Cp}$ : SOC, Tp and Ma are smaller than in non-trafficked soil.
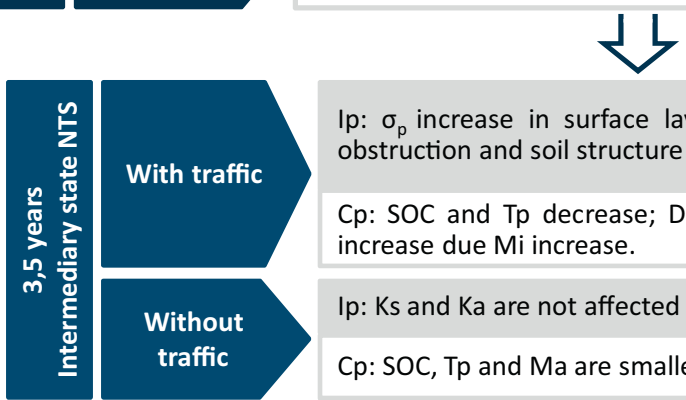

Ip: $\sigma_{\mathrm{p}}$ increase in surface layer; $\mathrm{Cc}$, Ks and Ka decreases due pore obstruction and soil structure (partially stable) colapse.

Cp: SOC and Tp decrease; DC and BD increase. Wr and Paw slightly increase due $\mathrm{Mi}$ increase.

Ip: Ks and Ka are not affected by traffic.

$\mathrm{Cp}$ : SOC, Tp and Ma are smaller than in non-trafficked soil.
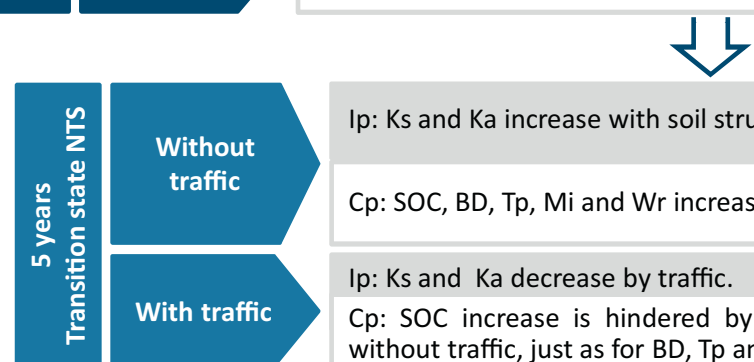

Ip: Ks and Ka increase with soil structure evolution.

Cp: SOC, BD, Tp, Mi and Wr increase; Ma decreases.

Ip: Ks and Ka decrease by traffic.

$\mathrm{Cp}$ : SOC increase is hindered by traffic, being lower than in soil without traffic, just as for BD, Tp and Ma.
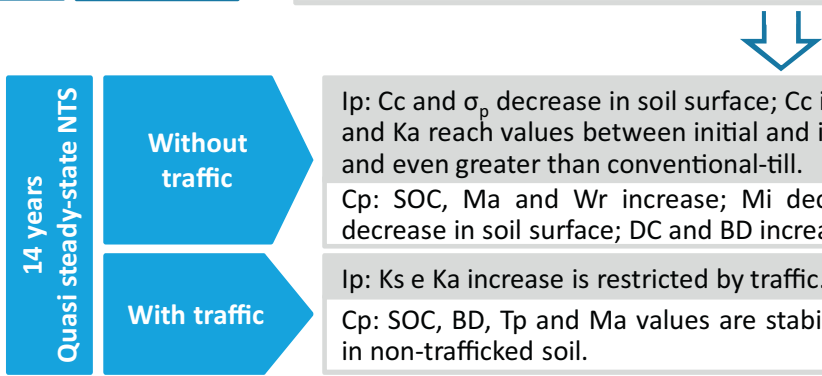

Ip: $\mathrm{Cc}$ and $\sigma_{\mathrm{p}}$ decrease in soil surface; $\mathrm{Cc}$ increase in subsurface. Ks and Ka reach values between initial and intermediary phase levels and even greater than conventional-till.

$\mathrm{Cp}$ : SOC, Ma and $\mathrm{Wr}$ increase; Mi decrease; Paw, DC and BD decrease in soil surface; $D C$ and $B D$ increase in subsoil.

Ip: Ks e Ka increase is restricted by traffic.

$\mathrm{Cp}$ : SOC, BD, Tp and Ma values are stabilized at levels lower than in non-trafficked soil.

Fig. 6. Framework for soil intensity (Ip, gray frame) and capacity ( $\mathrm{Cp}$, white frame) properties evolution in no-tillage system, with and without the effects of farm machinery traffic. 
properties: soil organic carbon, bulk density, pore size distribution, field capacity, and plant available water; and the intensity properties: soil precompression stress, compression coefficient, hydraulic conductivity, air permeability, and blocked porosity.

Changes in capacity and intensity properties are a consequence of soil pore and structure rearrangement (Fig. 7). We hypothesize the initial aggregates are still the anthropogenically-formed ones, while latter stages with pedogenetically-driven processes should produce bigger aggregates, and finally again smaller, more resistant ones. In this process, cracks create coarser aggregates, repeated swell and shrinkage followed by shearing results in small but rigid, and finally even mostly spherical aggregates. Thus, in principle, we could have the aggregate type sequence: prismatic, polyhedral, sub-angular blocks, and spheres. On the biological level a crumbly structure would be the final status, which is mostly macroscopically homogeneous.

Perturbing a steady-state increases entropy production, but when the perturbation is removed the system returns toward the steady-state, with entropy production declining toward an eventual minimum. Maintenance of the capacity for self-organization is essential for entropy minimization (Addiscott, 1995). Therefore, when replacing one ecosystem or agricultural production system by another it is important to achieve a steady-state and minimize entropy production. In our study 14 years of continuous no-tillage is the lowest entropy state near steady-state, but the soil remains in a "loosening" stage, where soil strength and soil functions can still be optimized.

\subsection{Summary of the discussion}

The concepts of entropy and capacity/intensity properties contribute to a better understanding of soil pore and structure rearrangement of soil under no-tillage and wheeling. The search for indicators to assess soil physical quality has been an exciting task for research in recent decades, due to complex interactions between soils and plants. These indicators are usually based on direct and indirect factors of plant growth, like resistance to root penetration, soil water availability and aeration, or other physical properties/processes.

Soil physical capacity parameters define a general status, i.e., composition of a given volume, but not their internal structure and function; while an intensity parameter includes dynamic aspects over time and space and thus encompasses the functionality and the reaction or processes of systems within the given environmental conditions. Intensity properties are related to the more dynamic processes of matter and energy flow and mechanical deformation of the soil matrix, and are highly depend on soil pore geometry and on aggregate resistance (Horn and Kutilek, 2009)

Linking capacity and intensity parameters, for our soil under various management systems, reveals the predominance of flux parameters to define the internal soil processes and the time dependency to reach a new, more dynamic equilibrium state, as suggested by Hartge and Horn (2009).

Farm machine traffic is a decisive factor for the sustainability of soil management systems, and may cause soil degradation or hinder the improvement of physical and hydraulic properties

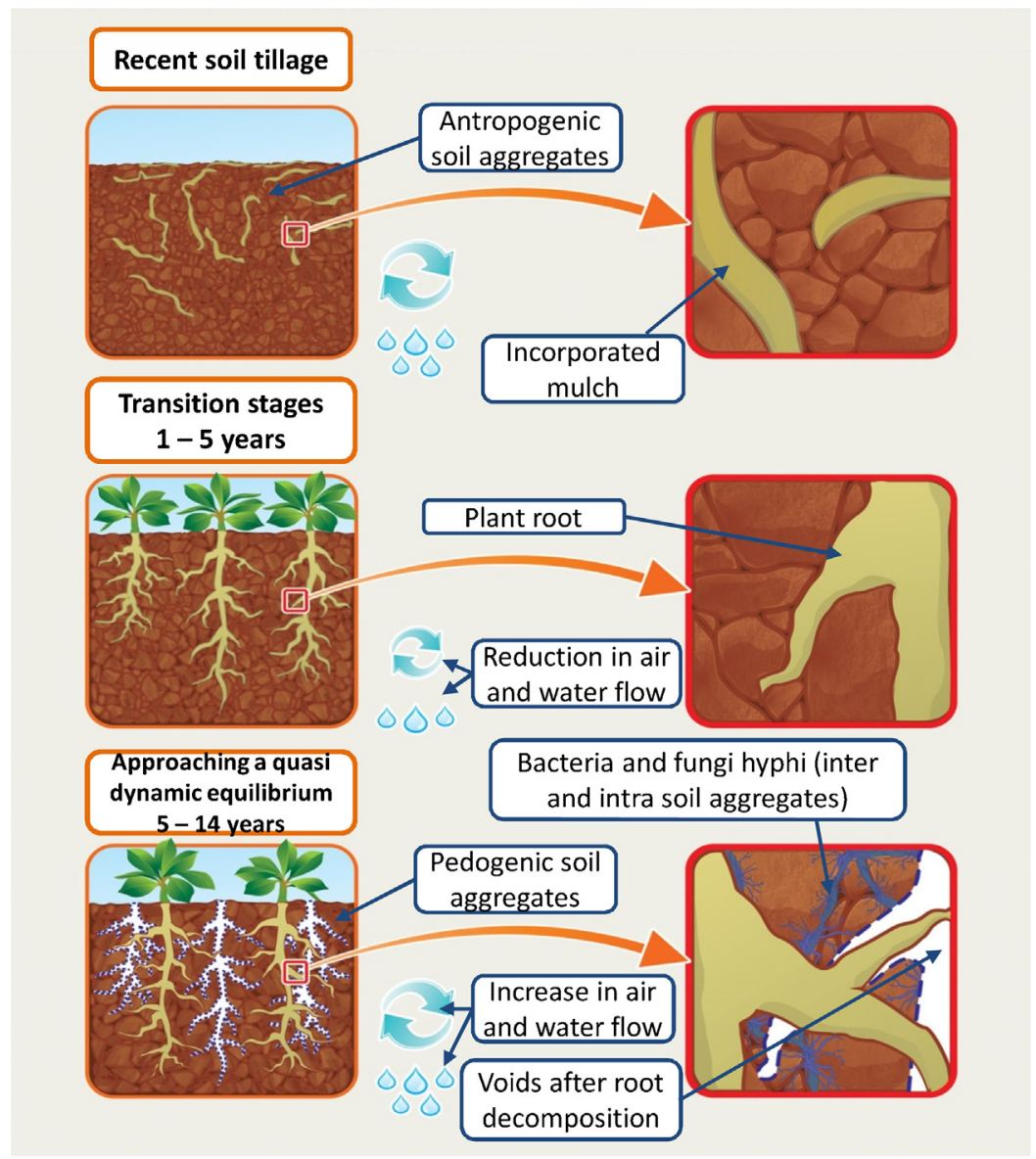

Fig. 7. Changes in soil structure with time of NTS adoption, for soil without farm machinery traffic. 
(Horn et al., 2003; Botta et al., 2011). Excessive traffic, i.e., above the soil load bearing capacity, promotes short-term impacts in pore structure by reducing macroporosity and increasing microporosity and bulk density, and thus reducing air and water permeability. In the long-term, this unfavorable condition for plant growth and development ultimately restricts the increase in organic matter, and does not favor soil structure reaching a new, improved equilibrium state.

\section{Conclusions}

Tillage of soil previously under no-tillage system significantly affects soil capacity properties, by resulting in high soil total porosity and macroporosity and low bulk density, and soil intensity properties, by increasing air permeability and saturated hydraulic conductivity, down to $21 \mathrm{~cm}$ in the soil profile. However, these changes due to soil tillage and disaggregation result in pore obstruction, decreasing water permeability and soil aeration, and in an increased precompression stress and soil susceptibility to compaction, i.e, higher strength coincides with smaller sensibility.

Farm machine traffic causes adverse effects in soil capacity properties, reducing soil total porosity and macroporosity, and increasing bulk density. This more compact soil structure constitutes an impediment to soil recovery and pore restructuring after tillage, especially in soil surface layer and during the first years of no-tillage, where soil is mostly unstructured and of low load bearing capacity in less dense soil. However, harmful effects of traffic become less noticeable with time of no-tillage and hence an increase in water retention is observed fourteen years after soil disruption by tillage.

After five years of no-tillage, there is an increase in microporosity and a small increase in soil organic carbon, especially in the uppermost soil layer, resulting in increased soil water retention and in plant available water, matric potential smaller than field capacity, and increase in soil intensity properties (soil water conductivity and air permeability), regardless of the effects of farm machinery traffic. Over time with soil reconsolidation, lower compression coefficient and lower degree-of-compactness occur in upper soil layers. In the deepest layer and in absence of soil disturbance there is an increase in soil degree-of-compactness and bulk density.

The proposed conceptual framework shows that results in capacity and intensity factors in controlled-traffic no-tillage soil is highly dependent on adoption time of no-tillage. We proposed that the following nomenclature to the different no-tillage states: initial (1.5 years), intermediary ( 3.5 years), transitional (5 years), and approaching a more stabilized stage (14 years).

The final stage of lowest entropy after 14 years of no-tillage is near steady-state, but still in "loosening" process, in which improvement of soil ecological properties and functions can still be optimized with respect to both soil strength and soil functions.

The proposed framework is valid for highly-weathered clayey soils, with kaolinitic and oxidic clays, and should possible also be applicable to sandier/siltier soils. However, for less-weathered soils with 2:1 type clays further studies are needed to test the validity of this framework.

\section{Acknowledgments}

We thank to CAPES,CNPq and Fapergs for financial support, to EMBRAPA for research facilities, and to Antonio Faganello and Rainoldo Alberto Kochhann for their work of field experiment prior to this research.

\section{References}

Abreu, S.L., Reichert, J.M., Reinert, D.J., 2004. Escarificação mecânica e biológica para a redução da compactação em Argissolo franco-arenoso sob plantio direto. Rev. Bras. Ciênc. Solo 28, 519-531.

Addiscott, T.M., 1995. Entropy and sustainability. Eur. J. Soil Sci. 46, 161-168.

Ahuja, L.R., Naney, J.W., Green, R.E., Nielsen, D.R., 1984. Macroporosity to characterize spatial variability of hydraulic conductivity and effects of land management. Soil Sci. Soc. Am. J. 48, 699-702.

Awe, G.O., Reichert, J.M., Timm, L.C., Wendroth, O.O., 2014. Temporal processes of soil water status in a sugarcane field under residue management. Plant Soil 387, 395-411.

Ball, B.C., O’Sullivan, M.F., Hunter, R., 1988. Gas diffusion, fluid flow and derived pore continuity indices in relation to vehicle traffic and tillage. J. Soil Sci. 39, 327-339.

Bernoux, C., Cerri, C.C., Cerri, C.E.P., Siqueira Neto, C., Metay, A., Perrin, A.S., Razafimbelo, T., Blavet, D., Piccolo, C., Pavei, C., Milne, E., 2006. Cropping systems, carbon sequestration and erosion in Brazil, a review. Agron. Sustain. Dev. 26, 1-8.

Bhattacharyya, R., Praksh, V., Kundu, S., Gupta, H.S., 2006. Effect of tillage and crop rotations on pore size distribution and soil hydraulic conductivity in sandy clay loam soil of the Indian Himalayas. Soil Tillage Res. 86, 129-140.

Bonumá, N.B., Rossi, C.G., Arnold, J.G., Reichert, J.M., Paiva, E.M.C.D., 2013. Hydrology evaluation of the soil and water assessment tool considering measurement uncertainty for a small watershed in southern Brazil. Appl. Eng. Agric. 29, 189200

Bonumá, N.B., Rossi, C.G., Arnold, J.G., Reichert, J.M., Minella, J.P., Allen, P.M., Volk, M., 2014. Simulating landscape sediment transport capacity by using a modified SWAT model. J. Environ. Qual. 41, 55-66.

Botta, G.F., Tolon-Becerra, A., Tourn, C., Lastra-Bravo, X., Rivero, D., 2011. Agricultural traffic: motion resistance and soil compaction in relation to tractor design and different soil conditions. Soil Tillage Res. 120, 92-98.

Braga, F.V.A., Reichert, J.M., Mentges, M.I., Vogelmann, E.S., Padrón, R.A.R., 2015. Propriedades mecânicas e permeabilidade ao ar em topossequência ArgissoloGleissolo: variação no perfil e efeito de compressão. Rev. Bras. Ciênc. Solo 39, 1025-1035.

Braida, J.A., Reichert, J.M., Veiga, M., da Reinert, D.J., 2006. Resíduos vegetais na superfície e carbono orgânico do solo e suas relações com a densidade máxima obtida no ensaio proctor. Rev. Bras. Ciênc. Solo 30, 605-614.

Braida, J.A., Reichert, J.M., Reinert, D.J., Sequinatto, L., 2008. Elasticidade do solo em função da umidade e do teor de carbono orgânico. Rev. Bras. Ciênc. Solo 32, 477-485.

Campbell, C.A., Selles, F., Lafond, G.P., Zentner, R.P., 2001. Adopting zero tillage management: Impact on soil $\mathrm{C}$ and $\mathrm{N}$ under long-term crop rotations in a thin Black Chernozem. Can. J. Soil Sci. 81, 139-148.

Casagrande, A., 1936. The determination of the pre-consolidation load and its practical significance. In: Proceedings of the International Conference on Soil Mechanics and Foundation Engineering, 1936, Cambridge. Cambridge, Harvard University, D-34, p. 60-64.

Cavalieri, K.C.V., Silva, A.P., Tormena, C.A., Leão, T.P., Dexter, A.R., Hakansson, I., 2009 Long-term effects of no-tillage on dynamic soil physical properties in a Rhodic Ferrasol in Parana, Brazil. Soil Tillage Res. 103, 158-164.

Chen, G., Weil, R.R., 2011. Root growth and yield of maize as affected by soil compaction and cover crops. Soil Tillage Res. 117, 17-27.

Czarnes, S., Hiller, S., Dexter, A.R., Hallett, P.D., Bartoli, F., 1999. Root:soil adhesion in the maize rhizosphere: the rheological approach. Plant Soil 211, 69-86.

da Veiga, M., Horn, R., Reinert, D.J., Reichert, J.M., 2007. Soil compressibility and penetrability of an Oxisol from southern Brazil, as affected by long-term tillage systems. Soil Tillage Res. 92, 104-113.

Dane, J.H., Vrugt, J.A., Unsal, E., 2011. Soil hydraulic functions determined from measurements of air permeability, capillary modeling, and high-dimensional parameter estimation. Vadose Zone J. 10, 459-465.

De Jong van Lier, Q., Gubiani, P.I., 2015. Beyond the least limiting water range: rethinking soil physics research in Brazil. Rev. Bras. Ciênc. Solo 39, 925-939.

Didoné, E.J., Minella, J.P.G., Reichert, J.M., Merten, G.H., Dalbianco, L., Barros, C.A.P., Ramon, R., 2014. Impact of no-tillage agricultural systems on sediment yield in two large catchments in Southern Brazil. J. Soils Sediments 14,1287-1297.

Engel, F.L., Bertol, I., Ritter, S.R., Paz González, A., Paz-Ferreiro, J., Vidal Vázquez, E., 2009. Soil erosion under simulated rainfall in relation to phenological stages of soybeans and tillage methods in Lages, SC, Brazil. Soil Tillage Res. 103, $216-221$.

Fabrizzi, K.P., Garcia, F.O., Costa, J.L., Picone, L.I., 2005. Soil water dynamics, physical properties and corn and wheat responses to minimum and no-tillage systems in the southern Pampas of Argentina. Soil Tillage Res. 81, 57-69.

Fasinmirin, J.T., Reichert, J.M., 2011. Conservation tillage for cassava (Manihot esculenta crantz) production in the tropics. Soil Tillage Res. 113, 1-10.

Gee, G.W., Bauder, J.W., 1986. Particle-size analysis, In: Klute, A. (Ed.), Methods of Soil Analysis. Part 1. 2nd ed. Agronomy Monograph 9, ASA and SSSA, Madison, WI, pp. 383-411.

Grzesiak, S., Grzesiak, M.T., Hura, T., Marcińska, I., Rzepka, A., 2012. Changes in root system structure, leaf matric potential and gas exchange of maize and triticale seedlings affected by soil compaction. Environ. Exp. Bot. 88, 2-10.

Gubiani, P.I., Reinert, D.J., Reichert, J.M., Gelain, N.S., Minella, J.P.G., 2010 Permeâmetro de carga decrescente associado à programa computacional para a 
determinação da condutividade hidráulica do solo saturado. Rev. Bras. Ciênc. Solo 34, 993-997.

Gubiani, P.I., Reichert, J.M., Campbell, C., Reinert, D.J., Gelain, N.S., 2012. Assessing errors and accuracy in dew-point potentiometer and pressure plate extractor measurements. Soil Sci. Soc. Am. J. 76, 19-24.

Hamza, M.A., Anderson, W.K., 2005. Soil compaction in cropping systems: a review of the nature, causes and possible solutions. Soil Tillage Res. 82,121-145.

Hartge, K.H., Horn, R., 2009. Die physikalische Untersuchung von Böden, 4th ed. Schweizerbart Verlag, Stuttgart ISBN: 978-3-510-65246-4.

Hazarika, S., Parkinson, R., Bol, R., Dixon, L., Russell, P., Donovan, S., Allen, D., 2009. Effect of tillage system and straw management on organic matter dynamics. Agron. Sustain. Dev. 29, 525-533.

Horn, R., 2004. Time dependence of soil mechanical properties and pore functions for arable soils. Soil Sci. Soc. Am. J. 68, 1131-1137.

Horn, R., Kutilek, M., 2009. The intensity-capacity concept-how far is it possible to predict intensity values with capacity parameters. Soil Tillage Res. 103, 1-3.

Horn, R., Peth, S., 2009. Soil structure formation and management effects on gas emission. Biologia 64, 449-453.

Horn, R., Smucker, A., 2005. Structure formation and its consequences for gas and water transport in unsaturated arable and forest soils. Soil Tillage Res. 82, 5-14.

Horn, R., Domżał, H., Słowińska-Jurkiewicz, A., Van Ouwerkerk, C., 1995. Soil compaction processes and their effects on the structure of arable soils and the environment. Soil Tillage Res. 35, 23-36.

Horn, R., Way, T., Rostek, J., 2003. Effect of repeated tractor wheeling on stress/strain properties and consequences on physical properties in structured arable soils. Soil Tillage Res. 73, 101-106.

Kaiser, D.R., Rodrigues, M.F., Reichert, J.M., Reinert, D.J., Horn, R., Fleige, H., Brandt, A. A., 2013. Soil physical capacity and intensity properties for achieving sustainable agriculture in the subtropics and tropics: a review. Adv. Geoecol. 42 282-339.

Kihara, J., Martius, C., Bationo, A., Thuita, M., Lesueur, D., Herrmann, L., Amelung, W., Vlek, P.L.G., 2012. Soil aggregation and total diversity of bacteria and fungi in various tillage systems of sub-humid and semi-arid Kenya. Appl. Soil Ecol. 58, $12-20$.

Klein, V.A., Reichert, J.M., Reinert, D.J., 2006. Água disponível em um Latossolo Vermelho argiloso e murcha fisiológica de culturas. Rev. Bras. Engenharia Agrícola e Ambiental 10, 646-650.

Klute, A., 1986. Water retention: laboratory methods, In: Klute, A. (Ed.), Methods of Soil Analysis: Physical and Mineralogical Methods. 2nd ed. American Society of Agronomy, Madison, pp. 635-660.

Krzic, M., Buhner, C.E., Teste, F., Dompter, L., Rahman, S., 2004. Soil properties influencing compactability of forest soils in British Columbia. Can. J. Soil Sci. 84, 219-226.

Lal, R., 2009. Challenges and opportunities in soil organic matter research. Eur. J. Soil Sci. 60, 158-169.

Li, D., Liu, M., Cheng, Y., Wang, D., Qin, J., Jiao, J., Li, H., Hu, F., 2011. Methane emissions from double-rice cropping system under conventional and no tillage in southeast China. Soil Tillage Res. 113, 77-81.

Mentges, M.I., Reichert, J.M., Rodrigues, M.F., Awe, G.O., Mentges, L.R., 2015. Capacity and intensity soil aeration properties affected by granulometry, moisture, and structure in no-tillage soils. Geoderma 263, 47-59.

Møldrup, P., Olesen, T., Komatsu, T., Schjønning, P., Rolston, D.E., 2001. Tortuosity, diffusivity, and permeability in the soil liquid and gaseous phases. Soil Sci. Soc. Am. J. 65, 613-623.

Mordhorst, A., Zimmermann, I., Peth, S., Horn, R., 2012. Effect of hydraulic and mechanical stresses on cyclic deformation processes of a structured and homogenized silty Luvic Chernozem. Soil Tillage Res. 125, 3-13.

Nicolis, G., Prigogine, I., 1977. Self-organization in Nonequilibrium Systems: From Dissipative Structures to Order Through Fluctuations. Wiley, New York.

Paterson, E., Gebbing, T., Abel, C., Sim, A., Telfer, G., 2007. Rhizodeposition shapes rhizosphere microbial community structure in organic soil. New Phytol. 173, 600-610.
Reichert, J.M., Suzuki, L.E.A.S., Reinert, D.J., Horn, R., Hakansson, I., 2009. Reference bulk density and critical degree-of-compactness for no-till crop production in subtropical highly weathered soils. Soil Tillage Res. 102, 242-254.

Reichert, J.M., Bervald, C.M.P., Rodrigues, M.F., Kato, O.R., Reinert, D.J., 2014 Mechanized land preparation in eastern Amazon in fire-free forest-based fallow systems as alternatives to slash-and-burn practices: hydraulic and mechanical soil properties. Agric. Ecosyst. Environ. 192, 47-60.

Reichert, J.M., Brandt, A.A., Rodrigues, M.F., Reinert, D.J., Braida, J.A., 2015a. Load dissipation by corn residue on tilled soil in laboratory and field-wheeling conditions. J. Sci. Food Agric. doi:http://dx.doi.org/10.1002/jsfa.7389.

Reichert, J.M., Rodrigues, M.F., Bervald, C.M., Brunetto, G., Kato, O.R., Schumacher, M. V., 2015b. Fragmentation, fiber separation, decomposition, and nutrient release of secondary-forest biomass, mechanically chopped-and-mulched, and cassava production in the Amazon. Agric. Ecosyst. Environ. 204, 8-16.

Reichert, J.M., Rodrigues, M.F., Bervald, C.M., Kato, O.R., 2015c. Fire-free fallow management by mechanized chopping of biomass for sustainable agriculture in Eastern Amazon: effects on soil compactness, porosity, and water retention and availability. Land Degrad. Dev. doi:http://dx.doi.org/10.1002/ldr.2395.

Reinert, D.J., Reichert, J.M., 2006. Coluna de areia para medir a retenção de água no solo: protótipos e teste. Ciênc. Rural 36, 1930-1935.

Rosa, D.P., Reichert, J.M., Sattler, A., Reinert, D.J., Mentges, M.I., Vieira, D.A., 2008. Relação entre solo e haste sulcadora de semeadora em Latossolo escarificado em diferentes épocas. Pesqui. Agropecu. Bras. 43, 395-400.

Schäfer, M.J., Reichert, J.M., Cassol, E.A., Eltz, F.L.F., Reinert, D.J., 2001. Erosão em sulcos em diferentes preparos e estados de consolidação do solo. Rev. Bras. Ciênc. Solo 25, 419-430.

Šimon, T., Javůrek, M., Mikanová, O., Vach, M., 2009. The influence of tillage systems on soil organic matter and soil hydrophobicity. Soil Tillage Res. 105, 44-48.

Soil Survey Staff, 2014. Keys to Soil Taxonomy. USDA-Natural Resources Conservation Service, Washington, D.C.

Suzuki, L.E.A.S., Reichert, J.M., Reinert, D.J., 2013. Degree of compactness, soil physical properties and yield of soybean in six soils under no-tillage. Soil Res. 51, $311-321$.

Suzuki, L.E.A.S., Reichert, J.M., Reinert, D.J., Lima, C.L.R., 2015. Degree of compactness and mechanical properties of a subtropical Alfisol with eucalyptus, native forest, and grazed pasture. For. Sci. 61, 716-722.

Trükmann, K., 2010. Quantifizierung der Stabilisierungseffekte von Pflanzenwurzeln als Möglichkeit zur Reduzierung der mechanischen Bodendeformationen in Grünland. PhD Thesis. CAU, Kiel.

Van Genuchten, M.T., 1980. A closed-form equation for predicting the hydraulic conductivity of unsaturated soils. Soil Sci. Soc. Am. J. 44, 892-898.

Vogelmann, E.S., Mentges, M.I., Reichert, J.M., da Rosa, D.P., de Barros, C.A.P., Reinert, D.J., 2012a. Compressibilidade de um Argissolo Vermelho-Amarelo trafegado e escarificado. Ciênc. Rural 42, 291-297.

Vogelmann, E.S., Prevedello, J., Reichert, J.M., Barros, C.A.P., Quadros, F.L.F., MataixSolera, J., 2012b. Soil hydro-physical changes in natural grassland of southern Brazil subjected to burning management. Soil Res. 50, 465-472.

Walkley, A., Black, I.A., 1934. An examination of Degtjareff method for determining soil organic matter, and proposed modification of the chromic acid tritation method. Soil Sci. 37, 29-38.

Wohlenberg, E.V., Reichert, J.M., Reinert, D.J., Blume, E., 2004. Dinâmica da agregação de um solo franco-arenoso em cinco sistemas de culturas em rotação e em sucessão. Rev. Bras. Ciênc. Solo 28, 891-900.

Wu, T.H., Watson, A., 1988. In-situ shear test of soil blocks with roots. Can. Geotech. J $35,579-590$.

Zibilske, L.M., Bradford, J.M., Smart, J.R., 2002. Conservation tillage induced changes in organic carbon, total nitrogen and available phosphorus in a semi-arid alkaline subtropical soil. Soil Tillage Res. 66, 153-163. 